Article

\title{
Why the Wind Curtailment of Northwest China Remains High
}

\author{
Guoliang Luo ${ }^{1,2, *}$, Erli Dan ${ }^{1}$ (D), Xiaochun Zhang ${ }^{1}$ and Yiwei Guo ${ }^{1}$ (i) \\ 1 School of Economics and Management, North China Electric Power University, Beijing 102206, China; \\ erlidan@ncepu.edu.cn (E.D.); Zhangxiaochun@ncepu.edu.cn (X.Z.); guoyiwei@ncepu.edu.cn (Y.G.) \\ 2 Beijing Key Laboratory of New Energy and Low-Carbon Development, \\ North China Electric Power University, Beijing 102206, China \\ * Correspondence: lg1365365@126.com
}

Received: 5 January 2018; Accepted: 6 February 2018; Published: 24 February 2018

\begin{abstract}
The total grid-connected installed capacity of wind power in northwest China has grown from 16,260 MW in 2013 to 43,290 MW in 2016; an increase of 88.7\% each year. However, this region has suffered from increasingly serious wind curtailment since 2014, and the wind curtailment amount accounts for nearly a half of China's total. The wind curtailment rate of Gansu Province, Xinjiang Uygur Autonomous Region and Ningxia Hui Autonomous Region in this area has increased and remains high. This paper constructs an analytical model to explore the reasons of the high wind curtailment of these three provinces from the four aspects of the wind power supply capacity, demand, grid transmission capacity, power system flexibility and market mechanism and laws. The results show that the relationship between the wind energy distribution and supply and the local load is incompatible, which is the source causing the high wind curtailment in northwest China. On the one hand, the game between the local government and developers has driven the development of wind power bases. On the other hand, the electricity sector is growing slowly and oversupply of electricity is seen in many areas of China. The wind power grid of northwest China not only faces limit of grid transmission capacity, but also constraint of insufficient flexibility of the electricity system. Presently, China has not set up a market mechanism and subsidy mechanism for the peak load adjustment, thus the thermal power companies lack motivation to voluntarily adjust the peak load. Moreover, the regional segregation and market barriers are also obstacles for the wind power outward transmission.
\end{abstract}

Keywords: northwest China; wind curtailment; transmission capacity; power system flexibility; penetration rate; accommodation; market mechanism

\section{Introduction}

In 2008, China's wind power started to grow rapidly, marked by the approval of a 10,000 MW wind power base in Jiuquan, Gansu Province, opening a new chapter of the new energy construction of China [1]. Since then China's installed capacity of wind power continued to rise, showing a "blowout" situation with construction of eight 10,000 MW-class new energy bases being approved, forming a mode of large-scale, concentrated development and long-distance transmission [2]. The total installed capacity of wind power connected to the grid was 148,640 MW in 2016, which is 16.7 times that of 2008 [3] (Figure 1), creating a miracle in the history of the new energy development of the world. While making great achievements, China saw a growing problem of wind curtailment [4]. It has become a focus of the whole society on how to improve the new energy utilization rate and reduce the electricity being curtailed. 


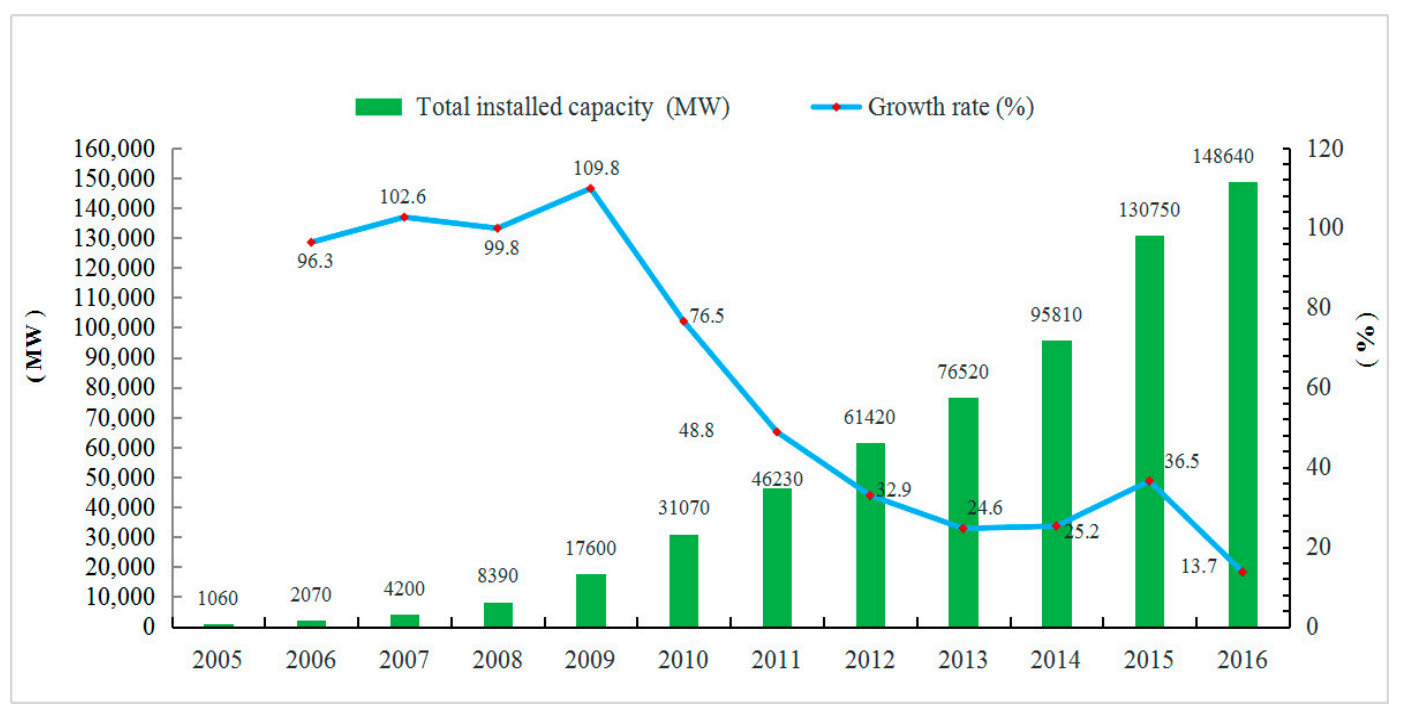

Figure 1. Development of the grid-connected installed capacity of wind power between 2005 and 2016 [3].

The electricity system simultaneously realizes power generation, supply and consumption and the electricity load shows obvious time-variant characteristics. The peak-valley difference of the power grid in northwest China has exceeded $30 \%$, and shows a growing trend. A basic condition for the electricity system to run steadily is that the system adjustment capacity must be higher than load fluctuation [5]. Because of the characteristics of wind and solar energy as resources, the output of new energy features randomness and fluctuation. The daily fluctuation of the wind power can be as high as $80 \%$ of the installed capacity, and shows some features of anti-peak load adjustment. When the new energy such as wind power is connected to the electricity system at a high proportion, the burden of electricity system is increased. The conventional power sources not only need to change with the load changes, but also need to balance the output fluctuation [6]. When the wind power output exceeds the system adjustment scope, efforts must be made to control the output so as to realize the system dynamic balance, resulting in wind curtailment.

China's wind curtailment is characterized by imbalance of regional development of wind power [7]. The contrary distribution of the wind resource and load and the large-scale concentrated development make China a country with the highest access voltage and the longest transmission distance of wind power [8]. China's wind power is mainly distributed in northwest China, North China and Northeast China which enjoy rich wind resources and account for more than two thirds of the total installed capacity of China [3]. Different from Germany, Spain and Denmark that feature dispersed distribution and local consumption of wind power, China normally transmits the wind power through the high voltage line to a long distance. The wind power base of Jiuquan transmits the surplus wind power to the load center $1000 \mathrm{~km}$ away; the wind power base of Inner Mongolia also transmits the wind power to consumers more than $250 \mathrm{~km}$ away [7]. Provinces in western and northern China that enjoy abundant wind resources are far from the electricity consumers in eastern China, resulting in the high rate of wind curtailment. It is noteworthy that the wind curtailment rate has remained high in northwest China (Figure 2) that accounts for almost a half of China's total (the northwest China accounted for $49 \%$ and 48\% of China's wind curtailment in 2015 and 2016, respectively).

After the wind power is connected to the electricity system at a large scale, it brings non-negligible impacts on the stability, voltage, electricity quality and system backup of the electricity system because of fluctuation, randomness and intermittency of the wind power output [6]. However, the electricity system has to limit the wind power output to ensure safe and stable operation and balance of quantities of electricity to meet the requirements of peak load adjustment, voltage control, economic dispatching 
and frequency modulation and other tasks. However problems have been properly managed in the United States and Europe where renewable energy has developed well. The United States and Europe have developed wind power for nearly 20 years and taken a leading role in the technology, operation management and electricity market of the world [3]. Take Europe for example, that its wind power has developed rapidly can mainly be attributed to constant improvement of wind power control technology, rational planning and support and guidance of the electricity market. In 2012, the installed capacity of Denmark and Germany reached $40 \%$ and $15 \%$ and the wind power output accounted for $22 \%$ and $10 \%$, respectively [3]. The reason that Europe can maintain the relative high access of wind power is because that the oil-fired generators, gas-fired generators and pumped storage account for a high proportion in the power source, and a robust $400 \mathrm{KV}$ grid serves as an effective support of the wind power transmission in Europe. Moreover, European countries not only are obliged to accept all provisions on wind power, but also set forth strict technical requirements on the technology and norms of wind power grid connection, wind turbine performance and wind farm management.

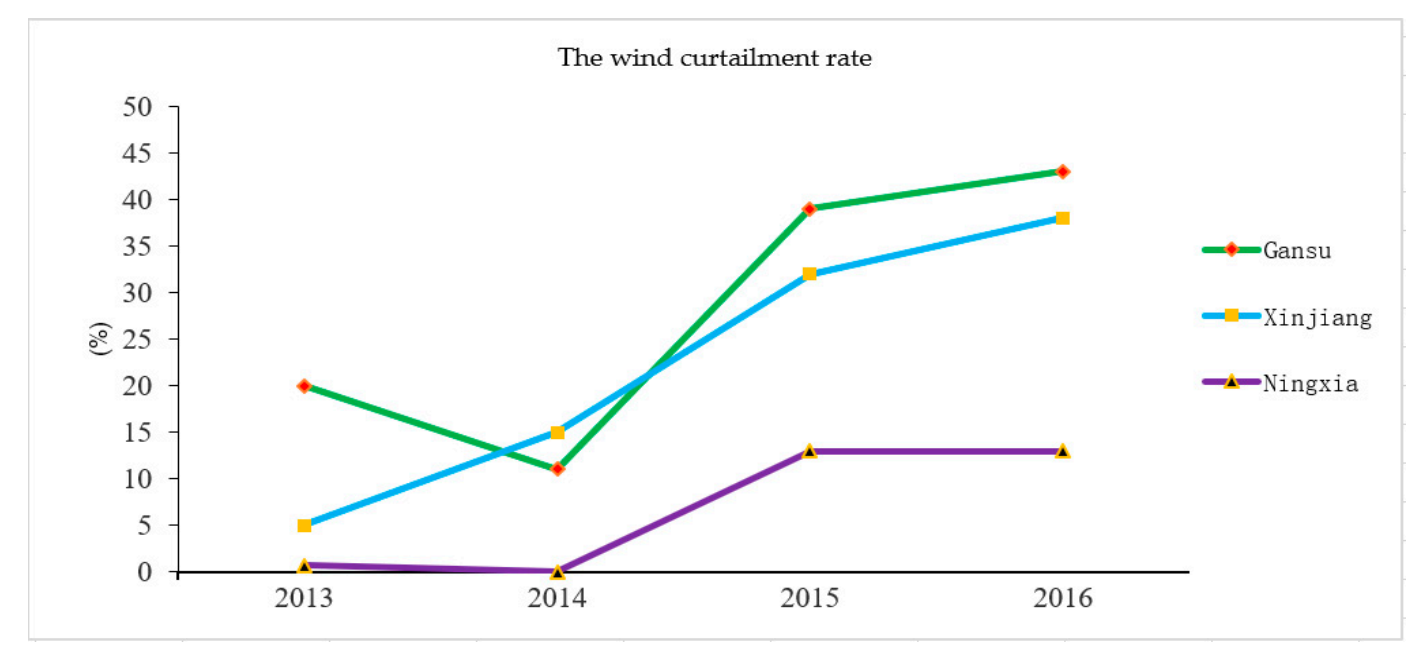

Figure 2. The wind curtailment rate of provinces in northwest China from 2013 to 2016 [3].

The most common explanation of the imbalanced development of wind power among different regions in China is distribution of wind resources. China boasts rich wind resource and the available potential wind energy exceeds 5500 GW (gigawatt) [9], but distributed quite unevenly among different regions. According to the research of He and Kammen of China's wind resource and wind power development potential [10], the potential of wind power development varies remarkably from province to province from less than $1 \mathrm{GW}$ to more than $600 \mathrm{GW}$. However, the distribution difference of the wind resource could not perfectly explain the huge regional differences of the wind power development that the wind resource utilization rate varies from less than $1 \%$ to $90 \%$ from province to province. Even in provinces with similar wind resource, the installed capacity varies highly.

Another even more perplexing question is why installed capacity has been increased rapidly while the region with rich wind resource has so serious wind curtailment since 2009. Take northwest China for example, the total installed capacity of wind power increased from 16,260 MW in 2013 to 43,290 MW in 2016, up 266\%. Meanwhile, the wind curtailment became even more serious, worsening the regional imbalance of the wind power development.

In 2010 China saw obvious wind curtailment and with rapid development of wind power, the electricity rationing became even more prominent. That year the newly increased installed capacity of wind power was $18,900 \mathrm{MW}$, the accumulative installed capacity ranked the world's first, and the total rationed electricity reached $3943 \mathrm{GWh}$, reaching 10\% [7]. In 2011, the rationed wind power in China exceeded 10,000 GWh. Large-scale wind curtailment became frequent and normalized in northeast and northwest China. The rationed electricity of Gansu, Inner Mongolia, Jilin and Heilongjiang reached 
5304 GWh, accounting for $50 \%$ of China's total; and the national electricity rationing reached $14.5 \%$ [7]. The year 2012 saw the most serious wind curtailment in history and the total rationed wind power hit $20,800 \mathrm{GWh}$, more than two times of that in 2011 , accounting for $14.7 \%$ of the total wind power output of the year, the highest in history [7]. In 2013, the wind curtailment rate started to decrease with concerted efforts of the government departments, grid companies and the wind power industry, and the rationed electricity reduced to $16,200 \mathrm{GWh}$, down $4600 \mathrm{GWh}$, the proportion of rationed electricity was reduced to $10.5 \%$, down 6.2 percentage points year-on-year. However, that did not mean the wind curtailment phenomena was bettered because the big wind power provinces still had high wind curtailment rate and Jilin and Gansu provinces still faced more than 20\% rationed electricity [7]. In 2014, the wind curtailment was obviously improved because of the generally lower wind force, and the rationed electricity was $12,600 \mathrm{GWh}$, and the average wind curtailment rate was $7.3 \%$, the lowest in recent years. The whole country, except Xinjiang, saw decreased wind curtailment rate to different extents, but the wind curtailment rate of northeast China, north China and northwest China was still relatively high, for example the rationed electricity of Xinjiang and Jilin reached $15 \%$. In the first half of 2015, the wind curtailment rebounded obviously and 17,500 GWh of wind power was curtailed, an increase of 10,100 GWh; and the average wind curtailment rate reached $15.2 \%$, up 6.8 percentage points year-on-year. It was even more serious in some areas. For example in the six big wind power provinces, namely Jilin, Gansu, Xinjiang, Heilongjiang, Inner Mongolia and Liaoning, the proportion of rationed electricity reached nearly or exceeded $20 \%$, and Jilin Province saw the highest, as high as $43 \%$. In the second half of 2015, the electricity rationing worsened in Gansu and Xinjiang etc. From July to October, the electricity rationing reached more than $50 \%$ monthly, unprecedentedly serious. In 2015 , more than 33,900 GWh of wind power was curtailed, and the wind curtailment rate exceeded $15 \%$, creating a new high in history [3]. The losses caused by wind curtailment almost offset the newly increased installed capacity in 2015.

In years between 2011 and 2015, China was the world's largest wind power market, but faced increasingly serious wind curtailment. According to the data of the National Energy Administration, the average use time of wind power was $1724 \mathrm{~h}$, a new lowest in the five years (2011-2015). In 2015, $33,900 \mathrm{GWh}$ of wind power was curtailed, an increase of 21,300 GWh year-on-year, and the average wind curtailment was 15\%. In 2016, the average wind curtailment was 17.1\% [3] (Figure 3), the highest since 2013 when the large-scale wind curtailment appeared for the first time. Gansu ranked first of all provinces with as high as $43 \%$ of the wind curtailment rate while Xinjiang's was $20 \%$. The wind curtailment rate remained high and showed an intensified trend. With growing grid-connected installed capacity, the wind curtailment in 2016 reached a new high in history with as high as 49,700 GWh of wind power being curtailed, an increase of 15,800 GWh compared with that in 2015, and almost four times of that in 2014. The curtailment resulted in as high as RMB 27 billion of electricity charge losses, equaling to nearly 16 million tons of standard coal equivalent [3]. Compared with the world's typical wind power countries that enjoy below $3 \%$ of the wind curtailment rate, northwest China's wind curtailment was strikingly high [11].

The high wind curtailment may result in a huge waste of renewable energy resources and power generation enterprises in losses, and seriously upset enterprises' investment enthusiasm. Consequently, the capital market started to upturn the risk assessment level of the wind power and PV industry. If the wind curtailment could not be solved as soon as possible, the renewable energy industry will fall into a vicious circle; the renewable energy development goals set in the 15th Five-Year Plan could not be realized, and the 2030 emission reduction goals and energy structure adjustment plan undertaken at the Paris Climate Change Conference will come to nothing [12,13]. 


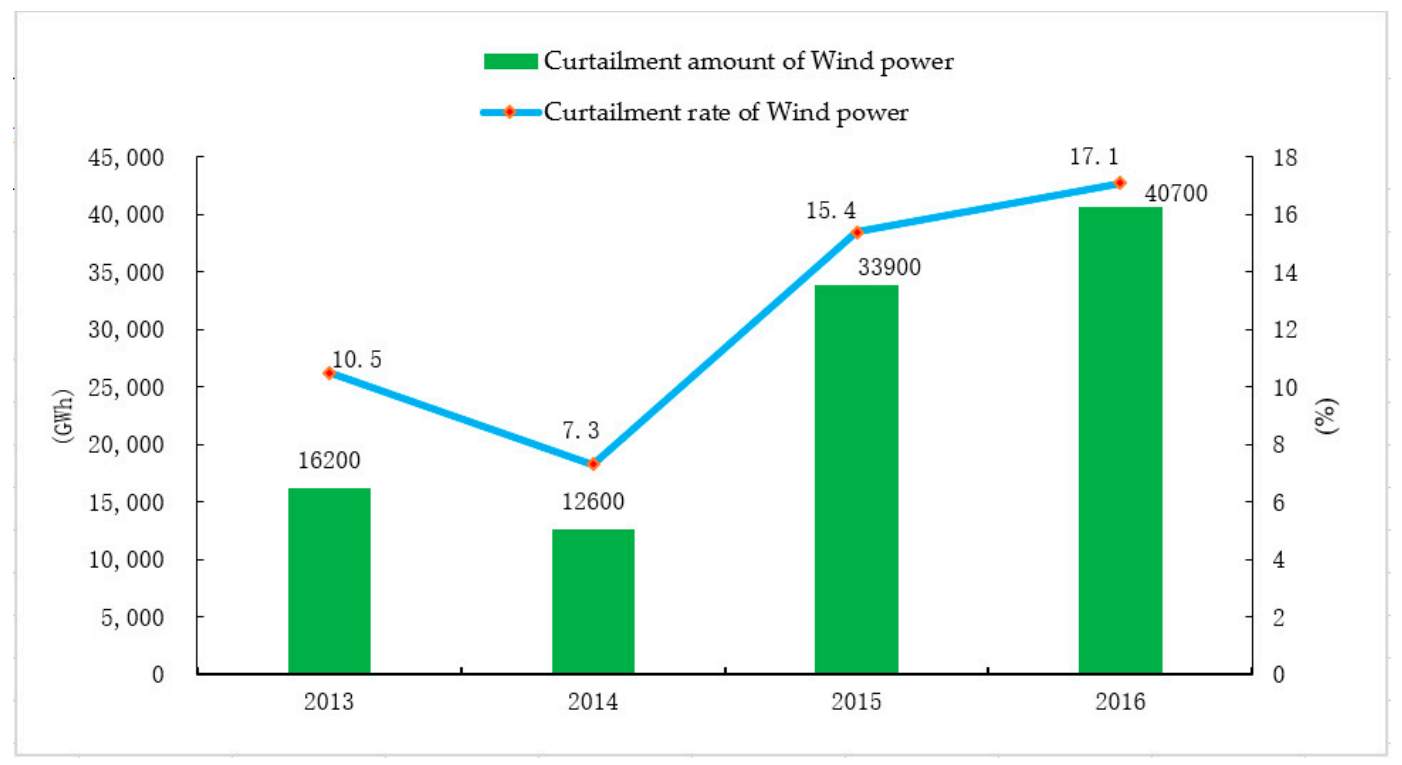

Figure 3. Change of wind curtailment rate of China between 2013 and 2016 [3].

Most of the studies on curtailing wind power in China are statements of common sense or obvious views. Some studies explore the impact of a certain factor on the development of wind power. For example, Zhang have discussed whether enlarging the outward transmission of wind power can solve the problem of curtailment of wind power [14]. It can be seen as another perspective to analyze whether the difficulties of outward transmission of wind power are the main reason for wind curtailment. Wei studied the role of local governments on the development of wind power, relevant laws and regulations in China [15]. A small number of empirical studies only analyzed some specific factors that affect wind curtailment from one aspect. Liu analyzed the impact of wind power integration on the existing power grid [16]. Zhang et al. analyzed the average annual government revenue and tax increase for 10,000 yuan of investment in thermal power or wind power of two typical districts based on the input-output method and concluded that thermal power generation has obvious advantages over wind power generation [17]. A large number of studies have subjectivity, one-sidedness and superficiality. In addition, they seem not like scientific papers for lack of necessary data analysis, which means further researches are needed. Therefore, it is impossible to figure out the main causes for wind curtailment. Thus these studies' contributions on how to solve the problem are limited. This paper attempts to construct a genesis analysis model, carry out a comprehensive analysis of the causes of wind curtailment, and use data analysis/case and scenario analysis method to clearly verify the model.

This paper aims at exploring why northwest China faced a large amount of wind curtailment and why the wind curtailment rate has remained high. Northwest China herein includes Gansu Province, Xinjiang Uygur Autonomous Region, Ningxia Hui Autonomous Region, Qinghai Province and Shaanxi Province. This paper mainly analyzes the first three provinces (autonomous regions) as Qinghai and Shaanxi has lower wind curtailment.

\section{Analytical Model}

Studies on the wind power operation and accommodation have different focuses and methods; some focus on the grid planning, construction and operation system analysis [18-22]; some center on the electricity market operation [23-26]; some discuss the coordination relationship between wind power characteristics and the electricity system [8,27]; some explain the flexibility of the electricity system [28-30]. Specifically, Pei et al. conducted an in-depth analysis of the operational characteristics and market consumption of China's wind power, pointing out that the mismatch 
between supply structure of domestic power and wind power development as well as insufficient capacity of cross-regional power transmission are the main reasons for low China's wind power consumption. Some researchers had studied the challenges of power grid brought by wind power integration and intended to design proposals to solve the problem. For example, the researches on the coordinated operation mode of combined heat and power generation, the combined operation strategy of peak power supply and intermittent power supply based on power grid security economy and the optimization of the operation and the market have the guidance meaning for policy making, which will help to ease the current tension of wind power consumption.

In addition to the qualitative analysis method, model demonstration and case study are used in the studies [31,32]. All these studies provide important inspirations for the establishment of the analytical framework and research of the paper.

From the aspect of the development process of renewable energy of the globe, only China is facing the large-scale wind power grid connection accommodation constraints in a large scope [3]. Compared with the United States and Europe, China faces many practical obstacles and challenges for the wind power accommodation.

First, China's electricity operation still follows the mode of planned economy. China's existing dispatching arrangement, from both the power generation side and the power consumption side, still adopts the management mode with characteristics of planned economy and flexible resources are lack of enthusiasm to voluntarily participate in the system balance adjustment. With regard to the electricity operation, though the Renewable Energy Law of China stipulates to implement the system of guaranteeing the purchasing of electricity generated by using renewable energy resources in full amount and power grid companies shall purchase in full amount the on-grid electricity of the grid-connected power generation projects which meet the grid connection technical standards in the coverage area of their power grids, the provisions that renewable energy resources shall be given priority and the full amount power grid connection are far from implemented.

Second, the cross-province electricity trading and transmission face obstacles. China has long been promoting construction of the electricity industry and the power market with province as an entity. Though in the past 30 years such practice has stimulated investment in the electricity industry and guaranteed power supply, the administrative provinces as executor of the planned economy of electricity industry have also hindered the cross-province electricity trading. The provincial electricity market led by the provincial government is characterized by the self-contained system and self-balance, making the relatively closed provincial market not conducive to optimizing the national electricity system planning, power source structure adjustment, the cross-province power grid operation, electricity trading, auxiliary services or renewable energy accommodation.

Third, there is a lack of a mechanism for demand-side response and energy storage and other flexible resources to participate in the market. In northwest, north and northeast China that face difficulties in the wind power accommodation, there is no demand-side management response and incentive mechanism that is conducive to the valley wind power accommodation such as the user-side peak-valley electricity price and time-of-use electricity price.

Based on above considerations, this paper constructs an analytical model (Figure 4) to comprehensively and systematically explore the causes of the imbalance development of wind power and worsening wind curtailment in northwest China. It includes the wind power supply capacity, electricity demand, power grid transmission capacity and electricity system flexibility and related market mechanism and laws, the four main elements impacting the wind power operation and accommodation in northwest China. 


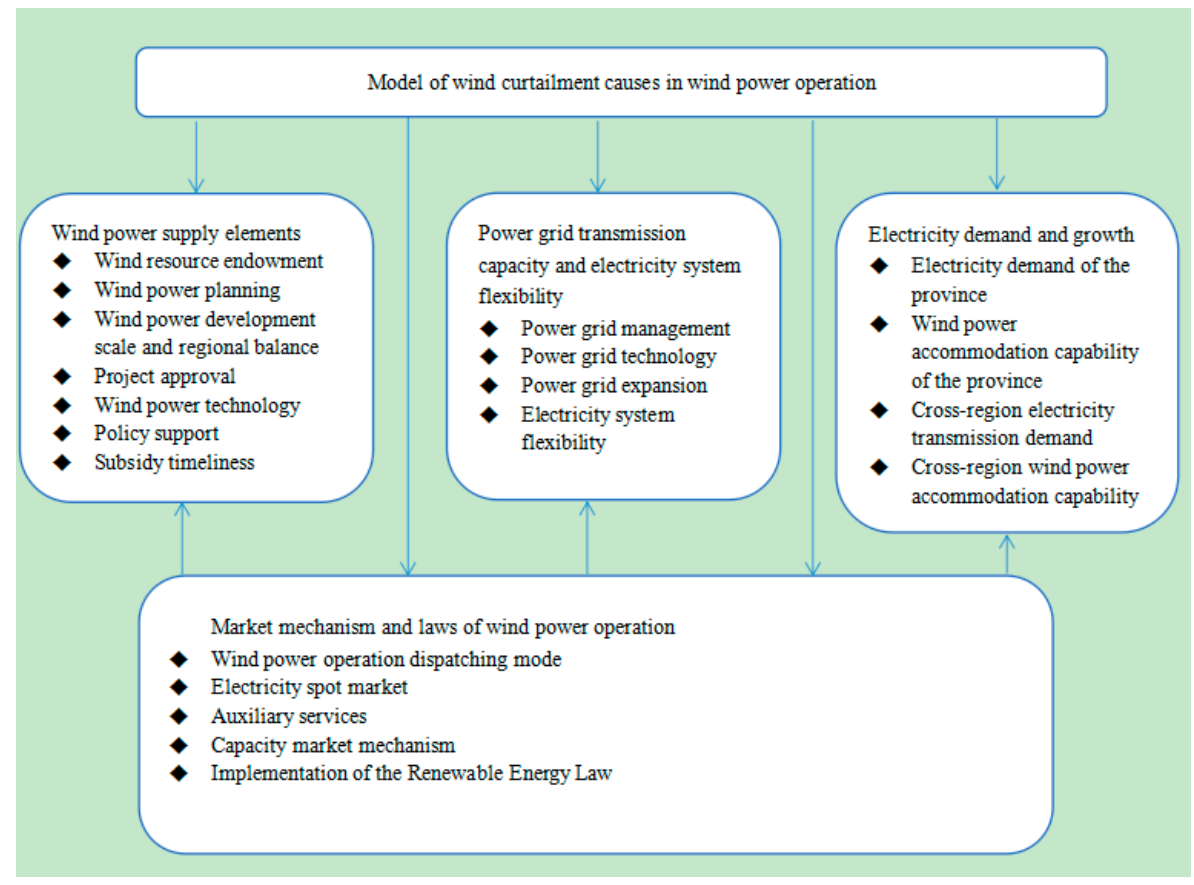

Figure 4. Analytical model.

\section{Analysis and Discussion}

\subsection{Factors Affecting Supply of Wind Power}

The supply of wind power generation is subject to choices of the investment main body. From the regional level, there is a balance level for installed capacity of wind power of a region [10] and this level is subject to a series of elements that influence the wind farm profitability [33-35], mainly including the resource endowment, for example wind resource and land conditions that can affect the wind power production costs; wind power support policy; wind power project planning and development; local economic development, and power grid that influence the wind power demand; alternative resources. The latter two elements will not be covered by this paper.

\subsubsection{Wind Resource Endowment}

China boasts rich wind resource and the available potential wind energy exceeds $5500 \mathrm{GW}$, but distributed quite unevenly among different regions (Figure 5) [36,37]. The wind resource in northwest China is extremely abundant. Most areas of Xinjiang Uygur Autonomous Region boast Grade I wind resource and Gansu's wind resource is rated at Grade II and III, Ningxia Hui Autonomous Region's Grade III and Shaanxi's Grade IV (Table 1); theoretically the wind resource endowment determines the potential supply capacity of wind power; the differences in the wind resource regional distribution determine the regional characteristics of wind power from the overall situation [38]. 


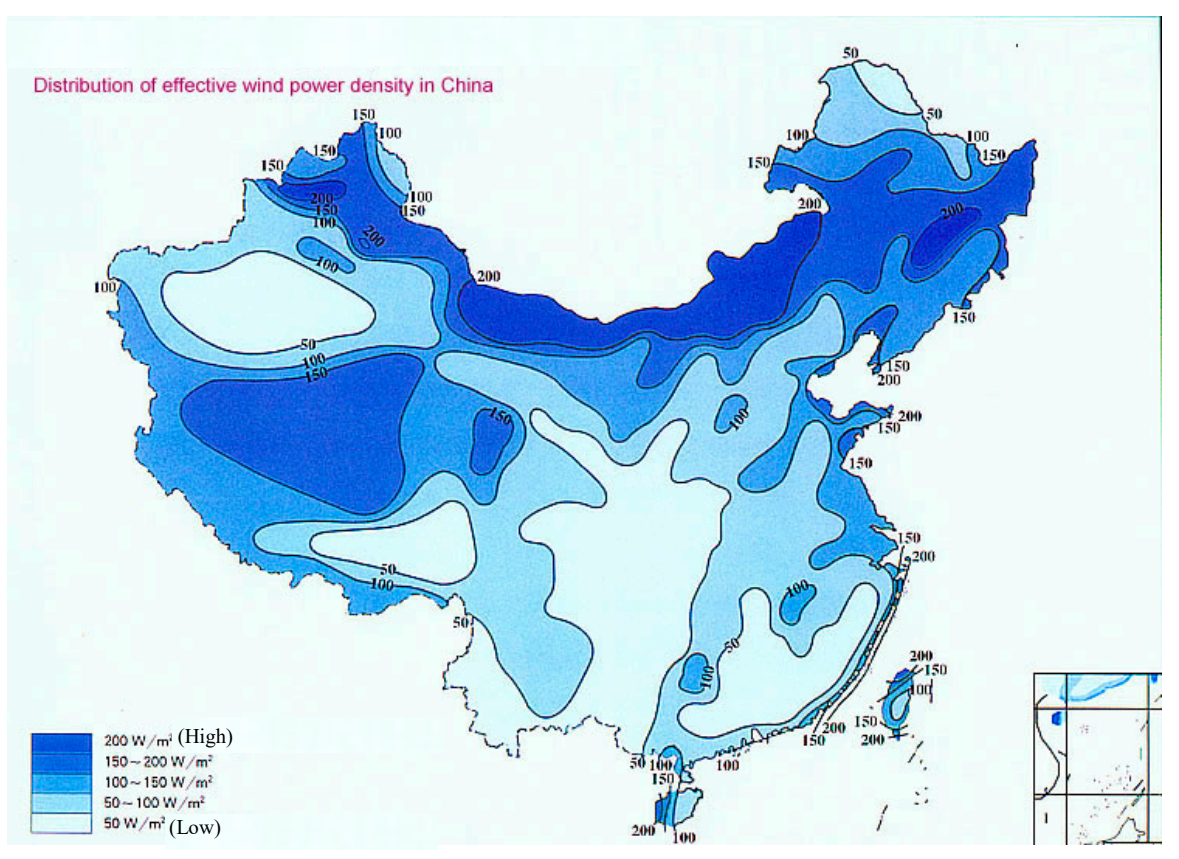

Figure 5. Distribution of effective wind power density in China.

\subsubsection{Grid-Connected Electricity Pricing Policy}

Wind power is a renewable energy technology with high maturity and strong market competitiveness and enjoys a promising development prospect. However, at the existing technology level and development scale, the wind power's cost is higher than the thermal power and cannot compete with thermal power under the market rule. Therefore, the wind power development cannot be separated from the government price policy support.

China's wind power pricing policy can clarify the wind power investment expectation so as to mobilize enthusiasm of investors to invest in wind power. China's wind power pricing policy evolution can be basically divided into three phases [39]. The first phase was the electricity price ratifying mechanism before 2003. In this phase the total installed capacity of wind power was lower and the competent authority approved the electricity price of wind power projects one by one. The second phase saw co-existence of bidding-based electricity price and ratified electricity price from 2003 to 2008 . The Chinese government held open bidding for the franchise of large-scale wind farms, introduced the competition mechanism into the wind farm development, determined the wind power on-grid price with the market way and guaranteed the electricity sales and on-grid price by signing the long-term contract. Then the bidding price became a basis for experienced provinces to build new wind power projects. The provinces that had no bidding experience still used the ratified electricity price. In this period, the regional differences of electricity prices were quite high, varying from RMB $0.38 / \mathrm{kWh}$ to RMB $0.8 / \mathrm{kW}$ [40]. The third phase started from 2009 when the fixed on-grid electricity pricing mechanism was implemented. The government divided the whole country into four zones according to the wind resource conditions and construction conditions and set up corresponding benchmark on-grid prices. The part of benchmark price of wind power higher than the thermal power price is covered by the fiscal subsidy, and the main source of fund is the renewable energy electricity price surcharges. In order to reasonably guide investment in the new energy industry, and promote the onshore wind power, PV power generation and other new energy projects to develop properly and healthily, enhance balanced development of new energy in various areas, and improve efficiency of the renewable energy electricity price surcharge subsidy, the benchmark pricing policy of newly built onshore wind power and PV power projects was adjusted in December 2015 (Table 1). 
Table 1. Onshore wind power benchmark on-grid pricing downturn of China (Unit: RMB/kWh) [40].

\begin{tabular}{|c|c|c|c|}
\hline Resource Zone & 2015 & 2016 & Areas Covered by the Zone \\
\hline $\begin{array}{l}\text { Grade I } \\
\text { resource zone }\end{array}$ & 0.49 & 0.47 & $\begin{array}{l}\text { Inner Mongolia except for Chifeng, Tongliao, Hinggan League and } \\
\text { Hulunbeir; Urumqi, Ili Kazak Autonomous Prefecture, Karamay City and } \\
\text { Shihezi of Xinjiang Uygur Autonomous Region }\end{array}$ \\
\hline $\begin{array}{l}\text { Grade II } \\
\text { resource zone }\end{array}$ & 0.52 & 0.50 & $\begin{array}{l}\text { Zhangjiakou and Chengde City of Hebei Province; Chifeng, Tongliao, } \\
\text { Hinggan League and Hulunbeier of Inner Mongolia Autonomous Region; } \\
\text { Zhangye, Jiayuguan and Jiuquan of Gansu Province }\end{array}$ \\
\hline $\begin{array}{l}\text { Grade III } \\
\text { resource zone }\end{array}$ & 0.56 & 0.54 & $\begin{array}{l}\text { Baicheng and Songyuan of Jilin Province;Jixi City, Shuangyashan City, } \\
\text { Qitaihe City, Suihua City, Yichun City and Daxinganling area of } \\
\text { Heilongjiang Province; Gansu Province except for Zhangye, Jiayuguan and } \\
\text { Jiuquan; Xinjiang Uygur Autonomous Region except for Urumq, Ili Kazak } \\
\text { Autonomous Prefecture, Changji Hui Autonomous Prefecture, } \\
\text { Karamay City and Shihezi City: Ningxia Hui Autonomous Region }\end{array}$ \\
\hline $\begin{array}{c}\text { Grade IV } \\
\text { resource zone }\end{array}$ & 0.61 & 0.60 & Other areas not covered by Grade I, II and III resource zones \\
\hline
\end{tabular}

The practice shows that the fixed electricity price zoning mechanism enhanced the development of the wind power industry.

\subsubsection{Wind Power and Wind Power Development Planning}

China's Five-year Plan for the national economic and social development and other industrial planning set forth the goals and direction for the national economic development. However, China was lack of a coordinated and unified electricity industry plan for a long time, which is one of the main elements causing curtailment of renewable energy resources. Since 2005, China's wind power industry has expanded rapidly. Inexplicably the 11th Five-Year Plan (2005-2010) and the 12th Five-Year Plan (2011-2015) of the electricity industry were not promulgated [41,42]. Without a unified planning for coordinated development of new energy power generation and electricity industry, some areas' installed capacity of wind power remarkably exceeded the reasonable accommodation capacity of the electricity system, resulting in a large amount of wind curtailment and seriously affecting benefits of wind power projects and healthy development of the wind power industry. Moreover, after the wind power project approval authorization was delegated to the lower level, the local government did not implement efficient supervision on the wind power and other renewable energy planning.

In 2014, the Decision of the State Council on Matters Concerning Administrative Approval Items to Be Canceled and Delegated to Lower Levels set forth that ratification of wind farm investment projects would be delegated to the investment authorities of local governments from the National Development and Reform Commission. Some areas even approved new projects outside of the national plan, resulting in worsening wind curtailment of wind farms in many areas [43,44]. It is thus concluded that the delegation of wind power project approval power to lower levels resulted in the management structure of "the central government governing planning and the local governments administrating projects". The local governments have limited planning and supervision capacity over the wind power and other renewable energy projects and saw remarkable growth of installed capacity of wind power (except for Gansu) and growing wind curtailment. Consequently the time of utilization of wind power equipment strikingly decreased [45] (Figures 6 and 7). 


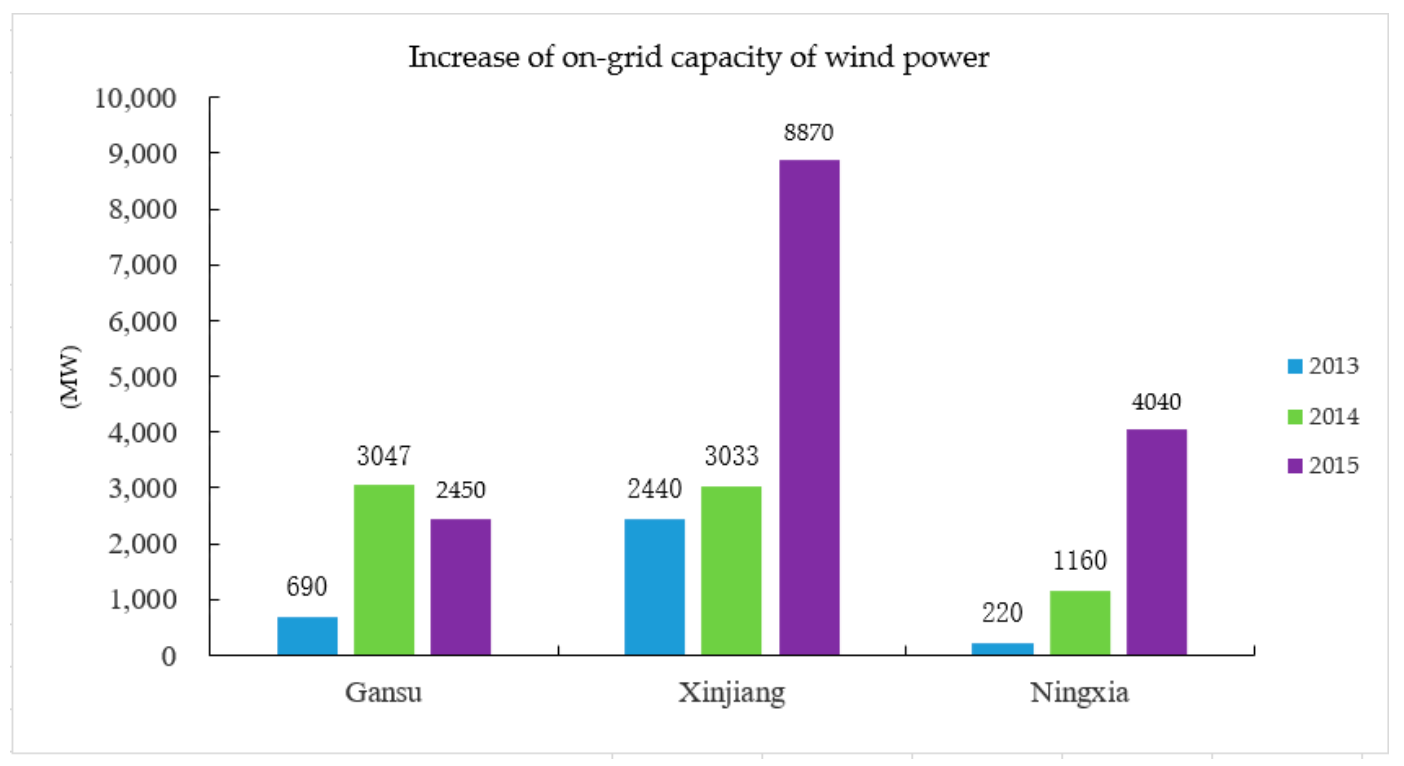

Figure 6. Newly increased on-grid capacity of wind power in northwest China 2013-2015 [45].

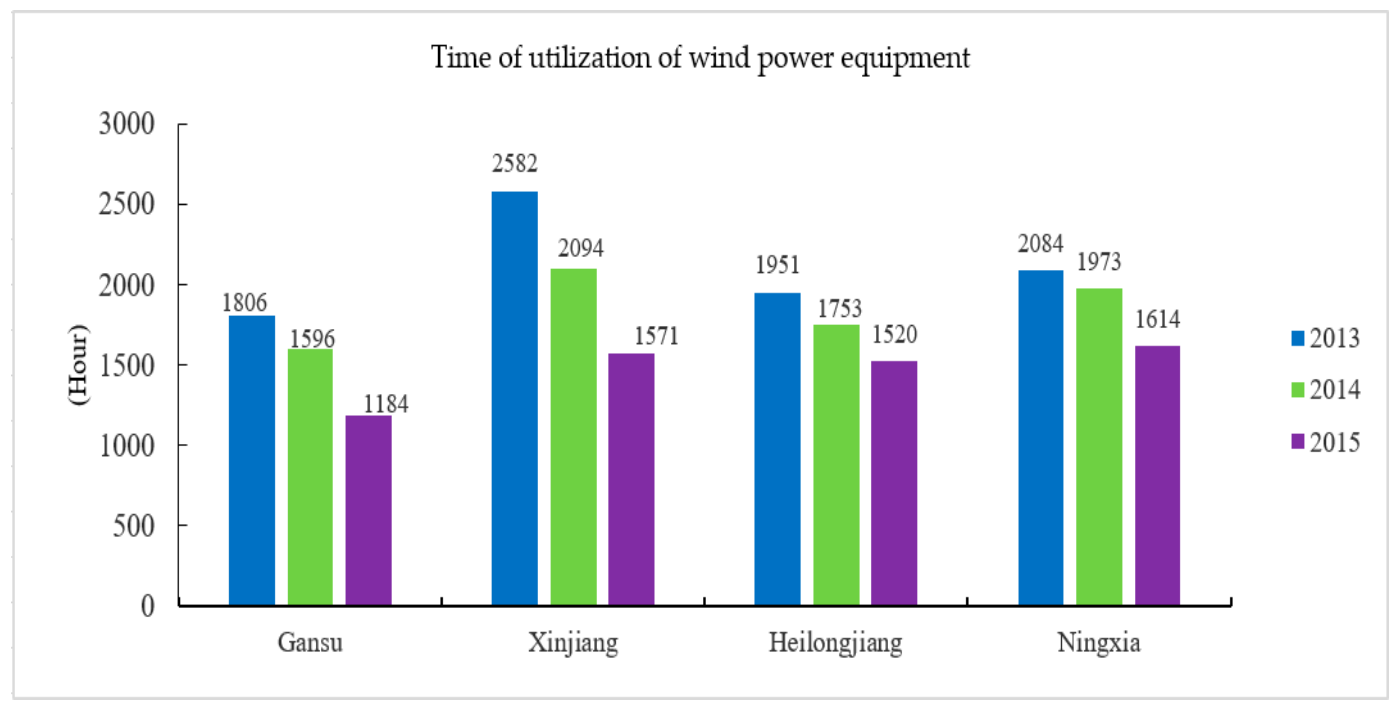

Figure 7. Time of utilization of wind power equipment in northwest China 2013-2015 [45].

\subsubsection{Wind Power Development Mode}

Distribution of China's power generation resources is obviously contrary to the electricity load. The wind resource is mainly distributed in northeast, north and northwest China. Therefore the wind farms and PV power plants are mainly developed with large-scale bases, resulting in the high proportion of installed capacity of new energy in northwest, north and northeast China. Nearly $90 \%$ of the installed capacity of wind power are located in 11 provinces, including Xinjiang, Gansu and Ningxia; and the proportion of installed wind power capacity accounting for maximum load of Gansu, Xinjiang and Ningxia has reached $96 \%, 77 \%$ and $74 \%$ respectively [34]. Take Gansu for example, the installed capacity of new energy in the period between 2011 and 2015 increased from $1500 \mathrm{MW}$ to 18,200 MW, 1.4 times of the maximum load of the province. Theoretically, the wind power and PV power generation capacity is equivalent to the maximum load, and the new energy scale is seriously unmatched by the local accommodation market (Figure 8). 


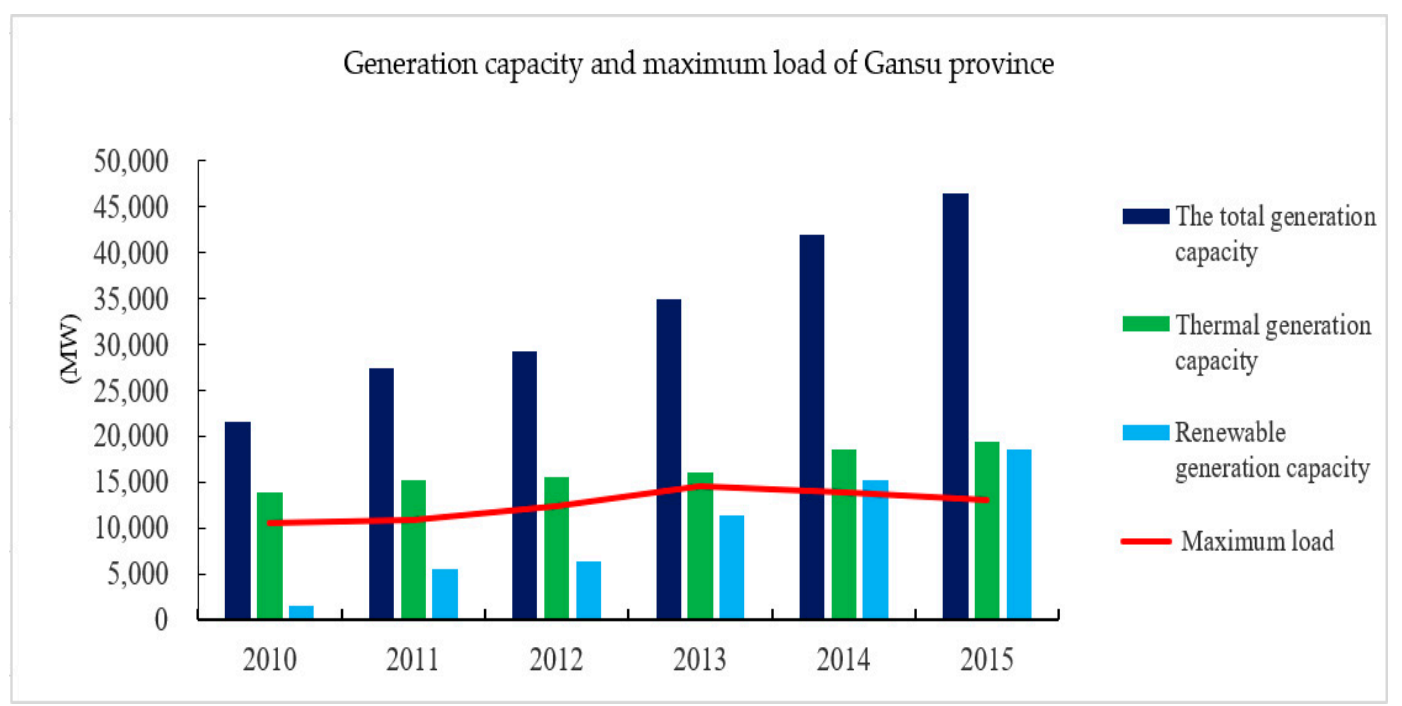

Figure 8. The total generation capacity, thermal generation capacity, renewable generation capacity, maximum load of 2010-2015 in Gansu [39].

Constrained by the economic development level, the areas with sufficient wind and light resources normally have insufficient demand on electricity and depend on external transmission channel to accommodate electricity. Gansu's maximum transmission capacity is about $3500 \mathrm{MW}$, and annual transmission amount is 16,400 GWh [34]. Therefore while the electricity demand from other areas does not grow rapidly and the external transmission channel is limited, Gansu's renewable energy development mode of relying on concentrated development and cross-province and cross-region utilization must result in difficulty in accommodation of wind power and the wind curtailment is unavoidable.

The central enterprises have served as a leading force in the large-scale wind power development. In recent years, the wind power developers' enthusiasm has been obviously improved with continuous support of the Chinese government to the new energy policies and gradual expansion of the wind power market. In 2013, China had 1235 wind power developers, including 960 state-owned enterprises, 114 private enterprises and 131 sino-foreign joint ventures. The state-owned enterprises accounted for $81.0 \%$ of China's accumulative installed grid-connected capacity (China Electricity Council, 2014); in 2015, the number of wind power developers declined by 434 enterprises to 801 , including 621 state-owned enterprises, 107 private enterprises and 41 sino-foreign joint ventures. The state-owned enterprises accounted for more than $81.0 \%$ of China's accumulative installed grid-connected capacity [46]. The five state-owned groups, namely China Guodian Corporation, Datang Group, China Huaneng Group, China Huadian Corporation, and China Power Investment Group, account for more than $55 \%$ of the accumulative grid-connected capacity and the generated electricity (Table 2). These large-scale state-owned enterprises have served as a leading force of China's wind power development.

Table 2. Proportion of installed capacity and generated electricity of the five central power corporations [46-49].

\begin{tabular}{cccccc}
\hline & $\mathbf{2 0 1 1}$ & $\mathbf{2 0 1 2}$ & $\mathbf{2 0 1 3}$ & $\mathbf{2 0 1 4}$ & $\mathbf{2 0 1 5}$ \\
\hline $\begin{array}{c}\text { Proportion of the five } \\
\text { corporations of installed } \\
\text { capacity of China's total }\end{array}$ & 69.48 & 63.59 & 60.80 & 58.43 & 54.78 \\
\hline $\begin{array}{c}\text { Proportion of the five } \\
\text { corporations' wind power of } \\
\text { China's total }\end{array}$ & 59.10 & 57.96 & 58.04 & 55.77 & 56.30 \\
\hline
\end{tabular}


The disputes of interests and gambling between local governments and developers drove development of the big wind power bases. The first is local governments. Take Gansu province for example. In 2011 the competent administration of Gansu pushed forward Phase II construction of Jiuquan Wind Power Base, but a large-scale wind power company raised objections at that time that Jiuquan's built wind farms' installed capacity exceeded $5000 \mathrm{MW}$ while the transmission line's capacity was only $5000 \mathrm{MW}$ to $6000 \mathrm{MW}$ and the line could not accommodate additional wind power. Though the developer insisted that Phase II should be developed after the power grid company enlarging the transmission capacity, Gansu Provincial Development and Reform Commission had control over the project and replied the developer with a tough decision: Constructing or losing the development right. Finally the developer had to complete the wind power development goal of $600 \mathrm{MW}$ (new installed capacity of wind power) with one year later than the schedule.

Second is the construction of the transmission grid. It will take at least two years for the State Grid Corporation of China to design and build transmission lines. Practically a transmission line could not transmit 12,000 MW at all, let alone the thermal power in addition. Moreover, the transmission line's design capacity is $6000 \mathrm{MW}$. Therefore Gansu province's plan was disjointed to the power grid planning.

Third is the state-owned wind power development enterprises. State-owned enterprises with autonomous rights and decision rights still invested in wind power project thought they had recognized that building new wind farms would definitely result in aggravating the situation of wind curtailment. When it knew an additional wind farm must result in the risk of? One of the reasons was constraints of the rationing system. Compared with non-state-owned enterprises, the state-owned enterprises pay more attention to supervision of the central government because whether ration is completed is closely related to appointment of senior executives of the state-owned power enterprises. The 12th Five-Year Plan for Development of Renewable Energy set forth to implement the renewable energy rationing system [50]. A document entitled Guiding Opinions on the Establishment of an Objective Leading System for Development and Utilization of Renewable Energy was promulgated by the National Energy Administration on 3 March 2016. It pointed out, "According to the requirement that the proportion of non-fossil energy of the total primary energy consumption should be improved to $15 \%$ by 2020 , the power enterprises' non-hydropower renewable energy generation should reach at least $9 \%$ of the total by 2020, except for the professional non-fossil energy producers, and the power enterprises can meet requirements on the proportion of non-hydropower renewable energy generation through certificate trading." As the most important investors of electricity industry, the five power corporations face pressure of rations. Wind power and PV power are the best marketed non-hydropower renewable energy of China and the total power generation of the two sectors basically represents the total non-hydropower renewable energy generation. In terms of wind power and PV power generation, the five corporations accounted for about $55 \%$ of China's total wind power. However, as shown in Table 3, Guodian Corporation accounted for the highest proportion of non-hydropower renewable energy generation, reaching $6.2 \%$, and Huadian Corporation the lowest, only $2.5 \%$. Constrained by the rationing system, these five corporations have inherent demand on investing in renewable energy (wind power and solar power). In order to seek future development and fulfill the rationing task, developers are competing for the limited wind resource development rights. Therefore it is not hard to understand that the state-owned wind power enterprise had to make concession to the tough administrative force of local government in order not to lose the Phase II wind power development right even though it knew the risk of wind power accommodation difficulties in the near future. 
Table 3. Proportion of wind power and PV power of the five power corporations of China's total power generation in 2014.

\begin{tabular}{|c|c|c|c|c|c|}
\hline Enterprise Name & $\begin{array}{c}\text { Total } \\
\text { Generation } \\
\left(10^{8} \mathrm{kWh}\right)\end{array}$ & $\begin{array}{l}\text { Coal Power } \\
\text { Generation } \\
\left(10^{8} \mathrm{kWh}\right)\end{array}$ & $\begin{array}{l}\text { Wind and PV } \\
\text { Power } \\
\text { Generation in } \\
\text { Total } \\
\left(10^{8} \mathrm{kWh}\right)\end{array}$ & $\begin{array}{l}\text { Proportion of Wind } \\
\text { Power and PV } \\
\text { Power Generation } \\
\text { of the Total Power } \\
\text { Generation (\%) }\end{array}$ & $\begin{array}{l}\text { Proportion of Wind } \\
\text { Power and PV } \\
\text { Power Generation } \\
\text { of the Coal Power } \\
\text { Generation }(\%)\end{array}$ \\
\hline Huaneng & 6013 & 5369 & 205 & 3.4 & 3.8 \\
\hline Huadian & 5349 & 4048 & 134 & 2.5 & 3.3 \\
\hline $\begin{array}{c}\text { State Power } \\
\text { Investment Corporation }\end{array}$ & 4263 & 3459 & 227 & 5.3 & 6.6 \\
\hline Datang & 4782 & 4146 & 178 & 3.7 & 4.3 \\
\hline Guodian & 5385 & 4247 & 332 & 6.2 & 7.8 \\
\hline
\end{tabular}

Source: based on data collected by the authors.

\subsection{Power Grid Transmission Capacity and Electricity System Flexibility of Northwest China}

The power grid accommodation capacity is mainly subject to the power source structure and peak load adjustment capability, power grid load level and load characteristics, wind power characteristics and wind power technology and equipment [30]. For northwest China, the wind power faces the challenges of the power grid transmission capacity constraint and insufficient flexibility of the electricity system.

From the relationship between the distribution of installed capacity of new energy and load, the installed capacity of northwest China is not distributed evenly, and contrary to the load. In 2015 northwest China only accounted for $10.5 \%$ of China's total load, but housed $34.8 \%$ of the installed capacity of new energy. The new energy penetration rate in Gansu, Ningxia and Xinjiang exceeded $100 \%$, surpassing developed countries such as Denmark, Spain and Portugal, as shown in Table 4. Because of the limited load scale of northwest China, the new energy accommodation brings higher requirements and huge challenge to the power source adjustment performance and power grid interconnectivity.

Table 4. Comparison of wind power and solar power installed capacity and new energy penetration rate in 2015 [30].

\begin{tabular}{cccc}
\hline Province, Country & $\begin{array}{c}\text { Wind Power Installed } \\
\text { Capacity (MW) }\end{array}$ & $\begin{array}{c}\text { Solar Power Installed } \\
\text { Capacity (MW) }\end{array}$ & Penetration Rate (\%) \\
\hline Gansu & 1252 & 610 & 143 \\
Ningxia & 822 & 309 & 102 \\
Xinjiang & 1691 & 529 & 100 \\
Qinghai & 47 & 564 & 73 \\
Denmark & 489 & 61 & 93 \\
Spain & 2298 & 709 & 78 \\
Portugal & 486 & 42 & 63 \\
\hline
\end{tabular}

3.2.1. Northwest China Wind Power Faces Constraints of Power Grid Transmission Capacity for Grid Accommodation

First, the existing energy system and infrastructure cannot accommodate large-scale renewable energy application.

In recent years, China saw growing wind curtailment, solar power curtailment and hydraulic power curtailment. With a growing proportion of renewable energy rationing, northwest China has serious wind curtailment and rationing. China lacks its own unified energy market and the development of cross-regional power transmission is lagging behind, resulting in serious electricity surplus in areas with rich energy. The conflict of interest between renewable energy and conventional 
energy and development space contradiction constrain the market space of renewable energy. In 2012 the wind power generation of Denmark, Germany, Finland and Spain accounted for 39\%, 24\%, 30\% and 33\% of their respective power generation [28]. In contrast, China's wind power generation in 2016 only accounted for $4 \%$ of the total power generation, and the proportion in northwest China was less than $3 \%$. Obviously, the existing energy system has not been ready for accommodating wind power in a large scale on the infrastructure, operation mechanism and technical configuration and can not adapt to the rapid changes of the electricity structure [51].

Second, it is impractical to accommodate the wind power locally. Thus transmission of electrical energy to other provinces through ultra-high voltage transmission line becomes a way to alleviate the problem of the wind curtailment in northwest China.

By the end of 2015 , more than $81 \%$ of the installed capacity of wind power was located in northeast, northwest and north China. The power grid and new energy enterprises have been counting on construction of cross-regional high-power electricity transmission channels to transmit wind power and other new energy to areas with demand. The State Grid Corporation of China started to construct the four cross-province ultra-high voltage (UHV) transmission projects, namely West Inner Mongolia-South Tianjin, Jiuquan-Hunan, Xilin Gol League-Jiangsu and Shanghaimiao-Shandong. Before construction of these four projects, Hami-Zhengzhou UHV Transmission Project has been completed. Because of the fluctuation characteristics of wind power and PV power, the UHV line is not to transmit electricity generated from new energy resources only, but must transmit thermal power together. The technology and economic performance decide that the line can transmit a very limited amount of new energy.

Moreover, the electricity consumption of the whole society has slowed down since 2015 and the thermal power faced serious surplus while the central government restricted approval and construction of new thermal power projects. The fact made the UHV wind power transmission to face new variables. What is more, the conflicts of interests among different regions still exist for transmitting the wind power through UHV line to the destination, leaving risks for the wind power outward transmission in future. The practice shows that because of the technological and economic reasons, the new energy UHV transmission project did not reach the anticipated effect. In 2016, non-hydropower renewable energy transmission only accounted for $14.5 \%$ of the total transmission of the five UHV lines; for example, the actual transmission capacity of Gansu Dunhuang-Jiuquan-Hexi-Wusheng $750 \mathrm{kV}$ transmission line was only 3200-4200 MW (not ideal design ability), much lower than the outward transmission demand of 16,000 MW of the installed capacity of renewable energy in west Gansu [52].

\section{A Case: Difficult Jiuquan UHV Transmission Project}

Jiuquan boasts abundant wind resources and attempted to build a wind power base of 10,000 MW level. Though the National Energy Administration approved Jiuquan to construct such a wind power base in 2011, the city completed investment of RMB 22.3 billion in wind power in 2010, and completed added value of RMB 6.005 billion, contributing $37.69 \%$ to the economic growth. Driven by the wind power industry, Jiuquan's GDP hit RMB 40.5 billion in the 11th Five-Year Plan period (2005-2010), fiscal revenue RMB 5.05 billion. However, the good times did not last long. With the economic downturn in 2015, the electricity consumption declined. From January 2015 to September 2016, the electricity consumption showed a negative growth in Gansu, leading to outbreak of the wind curtailment and electricity rationing. The contraction among different power sources became fierce. Since 2015 Gansu has counted on Jiuquan-Zhuzhou \pm 800 UHV DC transmission project to solve the wind curtailment. The UHV DC transmission project starts from Jiuquan, Gansu Province and ends at Zhuzhou, Hunan Province, passing through Gansu, Shaanxi, Chongqing, Hubei and Hunan, totaling $2413 \mathrm{~km}$ long. The designed transmission capacity is $7500 \mathrm{MW}$ and the total investment was RMB 24 billion. The erection of the UHV line can transmit surplus electricity of Gansu to Hunan to complement to each other's advantage for common development of the two provinces. In 2011 
the two provinces approved to construct the UHV DC transmission project. The situation became more complicated since 2012. In the previous year Hunan suffered from a serious shortage of power supply, and dispatched coal to guarantee the power supply. In 2012, Menghua Railway (from west Inner Mongolia to Central China) was approved and Hunan started to vigorously develop thermal power. In 2014, Hunan worked hard to develop a large-scale thermal power project in Yueyang with the construction of Menghua Railway. It planned to build four large power plants, with total installed capacity of 16,000 MW; Hubei Province, a terminal of Jiuquan-Hunan UHV DC transmission project, set forth its medium- and long-term development plan of large-scale thermal projects and planned to increase the total installed capacity of thermal power to 30,220 MW by 2015. Hunan applied to the National Energy Administration in 2014 to reduce purchase of electricity outside of the province because the thermal power and hydropower competed fiercely in the province, and consumption of thermal power reduced remarkably, resulting in difficulties of the thermal power plants. In 2015 Hunan reduced the electricity purchase again to $14,571 \mathrm{GWh}$, down $3.08 \%$ year-on-year [53].

The road to happiness is strewn with setbacks. With concerted efforts and negotiations among the National Energy Administration, Gansu Province and Hunan Province, Jiuquan-Hunan UHV transmission project was approved to construct in 2015. On 4 June 2017, the project passed the $168 \mathrm{~h}$ operation test and has conditions for official commercial operation [54].

\subsubsection{Electricity System Features Insufficient Flexibility and Faces Challenges}

With a growing renewable energy development and utilization scale, the output fluctuation, intermittency and forecast uncertainty of the renewable energy will bring great challenges to the planning and operation of the electricity system. If the conventional power sources are lack of sufficient flexibility, the output can hardly meet changes of renewable energy and its load; if the electricity system is lack of flexible operation, it cannot transmit and bear the flexible resources and will result in various safety risks. Therefore, freeing and improving flexibility of the electricity system will be a necessary and important task to accommodate renewable energy grid connection in a large scale and high proportion. In recent years, northwest China saw serious wind curtailment, solar power curtailment and electricity rationing. Northwest China's power source is mainly the traditional coal-fired thermal power, and the proportion of hydropower, pumped storage and gas-fired power plants with adjustment function is less than 1\% [55]. Especially in winter, the peak load adjustment capacity under the traditional technical plan and operation mode is very limited because of the high proportion of the thermal power units [56]. The United States and European countries have a high proportion of gas-fired power stations and pumped storage that can track load rapidly, and the proportion of flexible power sources accounted for nearly $50 \%$ of the total, and that of Spain reaches $35 \%$ [56]. More importantly, the large-scale thermal power projects of China still maintain the base-load power operation, and the flexibility of thermal power units has not been released, and the actual peak load adjustment service has been much lower than the world's leading level. So far, China still uses the thermal power adjustment indicators in assessments which were established in the early 1980s based on the coal power system. The thermal power units of different sizes and thermal power units in northwest China still use the traditional technical plan and operation mode, and no renovation, upgrade or operation mode adjustment was made according to requirements on flexibility. Based on the existing unit operation standards, the maximum peak load adjustment of China's thermal power units is 50\%; especially in northwest, northeast and north China with concentrated development of wind power, the adjustment range is even smaller (the minimum technical output of coal-fired heating unit is about 75\%), much lower than the leading level of Denmark and other countries [57] (Table 5).

Gansu has adjusted the peak load with coal power and hydropower. In 2016, the total installed capacity of coal power was 17,270 MW (cogeneration units accounted for a half of the total), the installed capacity of pumped storage power stations was $1200 \mathrm{MW}$, the installed capacity of wind power was 12,600 MW, and the grid-connected installed capacity of solar PV power was $6100 \mathrm{MW}$. However, from the perspective of technology, the maximum peak load adjustment capacity of pure condensing coal 
units in China is only $50 \%$ of the rated installed capacity, and the cogeneration units' is even smaller because of the impact of the policy of determining the power generation according to the heating load, and mostly units of $300 \mathrm{MW}$ and below participated in the power grid load adjustment [58]. Influenced by the coal power generation planning system, the coal power units must ensure a relative high time of use. Therefore, the limited unit adjustment space and constrained generation planning system resulted in insufficiency of adjustment flexibility of Gansu's electricity system. Gansu's wind power accommodation capacity is subject to the space of the valley load period deducting the minimum output of conventional power sources. The paper designs three scenarios and discovers with calculation that the minimum stable output of coal power plants is $30 \%$ even it does not supply heating. The installed capacity of power wind and PV power that is forced to be curtailed is $5411 \mathrm{MW}$. Actually, because the nonadjustable capacity of the electricity system occupies the limited electricity demand space, it has become a main element constraining the wind power output of Gansu (Table 6).

Table 5. Designated minimum stable output of power stations of Denmark [57].

\begin{tabular}{cc}
\hline Type of Power Source and Main Fuel & Minimum Output (\%) \\
\hline Conventional boiler coal-fired power plant & 35 \\
Oil-fired steam power plant & 20 \\
Gas-fired steam power plant & 20 \\
Biomass power direct-combustion power plant & 35 \\
Straw direct-combustion power plant & 50 \\
Gas turbine power plant & 20 \\
\hline
\end{tabular}

Table 6. Comparison of influence of flexible power source adjustment on Gansu's wind power and solar PV power accommodation scenarios.

\begin{tabular}{|c|c|c|c|}
\hline Scenario & $\begin{array}{l}\text { Minimum Stable } \\
\text { Output of Coal } \\
\text { Power Plant }\end{array}$ & $\begin{array}{l}\text { Acceptable Wind } \\
\text { Power and PV } \\
\text { Capacity (MW) }\end{array}$ & $\begin{array}{l}\text { Wind Power and PV } \\
\text { Power Installed } \\
\text { Capacity to Be } \\
\text { Curtailed (MW) }\end{array}$ \\
\hline $\begin{array}{l}\text { Scenario I: coal power plants } 17,270 \mathrm{MW} \text {, heat } \\
\text { supply period in winter; Installed capacity of } \\
\text { pumped storage power plant } 1200 \mathrm{MW}\end{array}$ & $60 \%$ & 6813 & 11,887 \\
\hline $\begin{array}{l}\text { Scenario II: all coal power plants } 17,270 \mathrm{MW} \text {, in the } \\
\text { non-heating supply period, installed capacity of } \\
\text { pumped storage power plants } 1200 \mathrm{MW}\end{array}$ & $50 \%$ & 9835 & 8865 \\
\hline $\begin{array}{l}\text { Scenario III: all coal power plants 17,270 MW, } \\
\text { no units for heating supply, installed capacity of } \\
\text { pumped storage power plants } 1200 \mathrm{MW}\end{array}$ & $30 \%$ & 13,289 & 5411 \\
\hline \multicolumn{4}{|c|}{$\begin{array}{l}\text { Source: based on data collected by authors. Note: In the winter heating supply period, half of coal power plants } \\
\text { are for heating supply; the minimum stable output of heating supply units is } 75 \% \text {. The calculation formulas are } \\
\text { as follows. }\end{array}$} \\
\hline \multicolumn{4}{|c|}{$\mathrm{Ap} c_{i}=\operatorname{InsP}+\sum_{i=1,2} \operatorname{Ins}_{i} \times\left(1-M s o_{i}\right)$} \\
\hline & $=E C-A p c_{i}$ & & \\
\hline
\end{tabular}

where $A p c_{i}$ denotes acceptable wind power and PV capacity; InsP is the installed capacity of pumped storage power plant, namely $1200 \mathrm{~W} ; i$ represents cogeneration units or non-heating supply units; $I n s_{i}$ is the installed capacity of $i ; M s o_{i}$ means the minimum stable output of $i ; C c_{i}$ denotes the curtailed installed capacity of wind power and PV power; EC is the existing capacity of wind power and photovoltaic power generation (18,700 MW). For Scenario II\& Scenario III, the installed capacity of cogeneration units is zero. 


\subsubsection{A Large Number of Self-Supplied Power Plants Affect the Electricity Peak Load Adjustment}

Affected by the existing pricing policy and management system, the self-supplied power plants and cogeneration units of China basically do not participate in the system load adjustment, directly constraining the thermal units to free flexibility.

Between 2011 and 2015, the self-supplied power plants in northwest China increased rapidly, more noticeably, the installed capacity of self-supplied power plants of Xinjiang was 16,290 MW, accounting for $45 \%$ of installed capacity of the thermal power (Table 7), and the installed capacity of self-supplied power plants in northwest China was about 25,180 MW [56]; the accumulative power generation has exceeded that of the public thermal power units, and the accumulative time of use reached $4886 \mathrm{~h}$, much higher than that of the public thermal power units' $2874 \mathrm{~h}$.

Table 7. Installed capacity of self-supplied power plants of provinces in northwest China in 2015 [56] (Unit: MW).

\begin{tabular}{ccccc}
\hline & Xinjiang & Gansu & Ningxia & Qinghai \\
\hline Installed capacity of self-supplied power plants & 16,290 & 4950 & 3500 & 440 \\
Proportion of installed capacity of coal units (\%) & 45 & 26 & 18 & 18 \\
2011-2015 average growth rate (\%) & 54 & 14 & 43 & 26 \\
\hline
\end{tabular}

The flexibility of thermal power units of northwest China is much lower than the world's leading level such as Denmark, and the technical potential has not been fully freed. Under the combined influence of the government pricing, the lack of a spot market of electricity, auxiliary service and capacity market system, the thermal power as the main power source has no incentive to release and improve its flexibility, seriously constraining the possibility of flexible operation and accommodating renewable energy of the electricity system.

\subsection{Market Mechanism and Legal Guarantee of Wind Power Operation}

Essentially the wind curtailment and rationing arose because the development of wind power touches the system arrangement of the traditional power market.

The six electricity system reform documents of China in the first batch set forth the mechanism framework of giving priority to renewable energy grid-connection and guaranteed purchase. For example, the Opinions on Promoting the Electricity Market Construction sets forth "to stick to giving priority to grid connection of clean energy forming a market mechanism promoting utilization of renewable energy. The renewable energy within the plan shall be given priority in the power generation, and transfer of power generation contract. Encouraging renewable energy to participate in the electricity market and cross-province and cross-region accommodation of renewable energy [59]. The Opinions on Orderly Opening the Power Generation and Consumption Plan puts forward "to establish the prioritized generation system" and include the renewable energy power source in the Grade I protection scope, "wind power, solar power and biomass and other renewable energy covered by the plan enjoy priority in the power generation, and generation capacity through full arrangement for the generation plan, and strict implementation of such plan". The Instructive Opinions on Enhancing and Standardizing Self-supplied Coal Power Plant Supervision and Management explicitly sets forth to "reduce coal consumption" and "promote replacement of the self-supplied coal power plants with renewable energy. In areas with abundant wind, light and water resources, efforts will be made to guide enterprises with self-supplied coal power plants to voluntarily reduce power generation of self-supplied power plants for self use and increase purchase from market with the market mechanism and gradually realize replacement of coal power with renewable energy" [59].

The traditional thermal units make every endeavor to be recognized as the heating supply units so as to refuse to involve in the peak load adjustment with the excuse of guaranteeing heating supply. The so-called technological problems have been proven not obstacles at abroad. In Germany, wind 
power, PV power and other volatile power sources account for more than $20 \%$ of the power grid, and in Denmark the proportion reaches nearly $40 \%$, but the power grid safety and stability is not affected. By analyzing the areas with serious wind curtailment, we can see the use of time of thermal power units is still as high as 3500-4000 $\mathrm{h}$, or even higher, and the system peak load adjustment and accommodation capacity of wind power (the peak load adjustment depth within $20 \%$, time of use 1500-2000 h) has not been fully tapped. The facts show that the main reason of wind and solar power curtailment is not the technical bottleneck, but the priority ranking of the new and old players of the electricity market and ultimately the problem of system arrangement. Under the existing electricity system, the thermal power enterprises enjoy the de facto priority with the planned generation designated by the government each year, squeezing the development space of renewable energy.

\subsubsection{Planned Dispatching of Electricity Operation Cannot Adapt to the New Energy Development}

Presently, the electricity operation dispatching follows the traditional planned method to quite a large extent and the time of operation of various kinds of power plants is mainly determined according to the annual generation plan, and the economic operation administration of various areas even assigns the generation plan to each unit. Because the annual power generation plan of thermal power is rigid, thermal power enterprises and local government are reluctant to give up the thermal power generation space. The dispatching department has to limit the generation space of renewable energy. This "planned" method cannot adapt to the fluctuation characteristics and requirements or guarantee priority of grid connection of renewable energy.

\subsubsection{Renewable Energy Law Implementation and Guarantee Not in Place}

It has been 10 years since the Renewable Energy Law came into effect. In this period, the law was amended in 2009.This law structures five systems supporting development of renewable energy, specifically the total amount objective, compulsory grid connection, classified pricing, costs sharing and special funds. But in execution, four of them are not fully and properly implemented.

First, the cost sharing is not implemented, resulting in a huge gap of the renewable energy power price surcharge.

As of the first half of 2016, the renewable energy subsidy gap has accumulated to RMB 55 billion. In the 10 years since the Renewable Energy Law came into effect, the renewable energy power price surcharge has been adjusted for three times and raised from the original RMB $0.001 / \mathrm{kWh}$ to RMB $0.019 / \mathrm{kWh}$. If collecting at the rate of RMB $0.019 / \mathrm{kWh}$, the renewable energy surcharge fund should reach RMB 80 billion in 2016, basically equaling to the amount of subsidy. But in fact, the collected surcharge was far below RMB 80 billion [60]. This is one of the important reasons that the subsidy could not be granted on time. An important reason causing the large subsidy gap is the rapid expansion of self-supplied power plants. Because such power plants pay no or very little to government-led funds, including the renewable energy power price surcharge, the theoretically collected amount of renewable energy surcharge is much higher than the actually collected amount.

Second, the pricing mechanism is not in place. According to provisions of the Renewable Energy Law, the on-grid price of renewable energy power consists of the conventional energy on-grid price and renewable energy surcharge. For example, China implements benchmark on-grid tariff policy for onshore wind power in different resource zones, and the part of the wind power on-grid price under the local coal unit benchmark on-grid price (including desulfurization, denitrification, dust removal) shall be borne by the local provincial power grid; the part higher than the benchmark price will be subsidized from the renewable energy surcharge by government. The implementation shows that the part from the power grid enterprise is in place, but the part from government is not granted fully.

Third, the compulsory grid-connection mechanism is not really implemented and has become normal. In 2016, the National Development and Reform Commission and the National Energy Administration ratified the minimum guaranteed purchase of annual use of time of wind power and $\mathrm{PV}$ power of main areas, and set forth requirements on the full-amount guaranteed purchase according 
to the Renewable Energy Law. However, the difference between actual use of time and the minimum guaranteed purchase of annual time of use of Xinjiang and Gansu can reach $750 \mathrm{~h}$ the highest (Table 8).

Table 8. Implementation of minimum guaranteed purchase of annual use of time of wind power in main areas in 2016.

\begin{tabular}{cccc}
\hline Province (Autonomous Region) & $\begin{array}{c}\text { Guaranteed Purchase } \\
\text { of Use of Time (h) }\end{array}$ & $\begin{array}{c}\text { Actual Use of } \\
\text { Time (h) }\end{array}$ & Difference (h) \\
\hline Xinjiang (Grade I) & 1900 & 1723 & -177 \\
Xinjiang (Grade III) & 1900 & 1209 & -591 \\
Gansu (Grade II) & 1800 & 1045 & -755 \\
Gansu (Grade III) & 1800 & 1179 & -621 \\
Ningxia (Grade III) & 1850 & 1553 & -297 \\
\hline
\end{tabular}

Source: Authors' own illustration.

Fourth, fiscal subsidy is not in place. It is predicted that the gap of renewable energy subsidy would exceed RMB 60 billion in 2016. To date, the fiscal subsidy of renewable energy was only granted to December 2014 [61].

\subsection{Electricity Demand and Wind Power Accommodation Capacity}

3.4.1. Electricity Demand in Northwest China Slows Down, Incapable to Accommodate the Total Market

Since 2013, the social consumption of electricity in main provinces of northwest China showed obvious fluctuation and decline (Table 9). Social consumption of electricity refers to the total electricity consumption of primary industry, secondary industry, tertiary industry and domestic consumption of urban and rural residents. The tertiary industry refers to the service sector, that is industry other than primary and secondary industries. Xinjiang saw the highest fluctuation of social electricity consumption, and the growth rate declined from $31.2 \%$ and $31.3 \%$ in 2013 and 2014 to $12 \%$ in 2016, a decline of nearly 20 percentage points. In 2016, Ningxia and Qinghai saw negative growth of the social consumption at $-3.0 \%$, and in the same year Gansu's social electricity consumption grew at $5.0 \%$, an increase of three percentage points compared with that of 2013, equaling to the country's average. The social electricity consumption of east, central and west China (including southwest and northwest) and north China grew at 5.9\%, 5.4\%, 3.7\% and $2.7 \%$, respectively. The east and central China saw a relative good situation and served as the main driving force of the power consumption [61].

Table 9. Changes of social consumption of electricity of main northwest provinces (Unit: \%).

\begin{tabular}{cccccc}
\hline Province (Autonomous Region) & $\mathbf{2 0 1 2}$ & $\mathbf{2 0 1 3}$ & $\mathbf{2 0 1 4}$ & $\mathbf{2 0 1 5}$ & $\mathbf{2 0 1 6}$ \\
\hline The whole country & 5.6 & 7.6 & 4.1 & 0.5 & 5.0 \\
Gansu & 7.8 & 2.0 & 0.3 & 1.0 & 5.0 \\
Xinjiang & 32.2 & 31.2 & 31.3 & 13.69 & 12.0 \\
Ningxia & 2.4 & 10 & 4.6 & 8.8 & -3.0 \\
\hline
\end{tabular}

Source: Authors' own illustration.

With the fluctuation and slowdown of the growth of the electricity demand in main provinces of northwest China, the installed capacity of various power sources, including wind power, has maintained a relative rapid growth [61].

Since 2010, Gansu saw a rapid growth of installed capacity and serious surplus of electricity production. Between 2010 and 2015, the installed capacity of Gansu grew 22.2\% on average, but the growth rate of electricity consumption in the same period was only $4.8 \%$. 
Xinjiang also saw a rapid growth of the installed capacity since 2010. From 2010 to 2015, the average growth of installed capacity grew by $68 \%$, but the electricity consumption grew by $14.0 \%$ only on average in the same period.

While the total electricity consumption was low, Ningxia increased the big users' direct purchase of thermal power, further squeezing the market space of new energy. At the beginning of 2015, Ningxia arranged direct dealing of 12,000 GWh between the public thermal power plants and big users, and additional $5000 \mathrm{GWh}$ dealing in September of the same year. This move significantly improved utilization rate of thermal power units in winter windy period, and caused skyrocketing wind curtailment in October in Ningxia at 32.7\%, an increase of 32.5 percentage points year-on-year.

According to Yuan Jiahai's research, the total load rate of electricity system showed a decline trend with increase of electricity consumption of the tertiary industry and residents. Therefore, the maximum load growth will be higher than the electricity generation growth. He said the maximum electricity load growth will be 1.4 times of the electricity consumption growth from between 2017 and 2020 [62]. And on this basis he estimated the electricity consumption and maximum load of various provinces of northwest China in 2020 (Table 10).

Table 10. Electricity load forecast of northwest provinces 2017-2020 [63-65].

\begin{tabular}{ccccc}
\hline Province & $\begin{array}{c}\text { Electricity } \\
\text { Consumption } \\
\text { Growth }\end{array}$ & $\begin{array}{c}\text { Maximum } \\
\text { Load Growth }\end{array}$ & $\begin{array}{c}\text { 2020 Electricity } \\
\text { Consumption } \\
\mathbf{( 1 0}^{\mathbf{8}} \mathbf{~ k W h )}\end{array}$ & $\begin{array}{c}\text { 2020 Maximum } \\
\text { Load (10 MW) }\end{array}$ \\
\hline Shaanxi & $5.8 \%$ & $8.1 \%$ & 1618 & 2786 \\
Gansu & $2.8 \%$ & $3.9 \%$ & 1260 & 1577 \\
Qinghai & $3.7 \%$ & $5.2 \%$ & 789 & 1079 \\
Ningxia & $5.2 \%$ & $7.3 \%$ & 1130 & 1573 \\
Xinjiang & $10.4 \%$ & $14.6 \%$ & 3545 & 5081 \\
\hline
\end{tabular}

In summary, in the period from 2017 to 2020, the electricity consumption growth rate of northwest provinces, except for Xinjiang that will see an electricity consumption growth of $10.4 \%$, will be below $6 \%$. According to a conservative estimate, even the wind power generation maintains a growth rate of $10 \%$ from 2017 to 2020, it is not practicable to accommodate wind power through increasing the electricity consumption in northwest China.

Moreover, if calculating by the average growth rate of wind power installed capacity in 2016, the wind power installed capacity of Gansu in 2020 will be 1.26 times of the maximum load of that year, the proportion of Ningxia's will be 0.93 . These data shows from another aspect that Gansu and Ningxia could hardly solve the wind curtailment by 2020.According to Xinjiang's calculation, the ratio between wind power installed capacity and the maximum load in 2020 will be 0.55 , but because of the large number of self-supplied power plants (about $50 \%$ of the self-supplied power plants are big energy consumers, and do not participate in the electricity system peak load adjustment), the ratio will exceed 1.00 if deducting the load of self-supplied power plants. Obviously Xinjiang's situation is not optimistic either and the wind curtailment could not be completed solved by 2020 .

3.4.2. Cross-Region Electricity Transmission Reduced, Thermal Power and Wind Power Cross-Region Transmission Hindered by Regional Demarcation and Market Blockade

Theoretically, the demand on wind power is subject to the electricity demand of transmission destination and its accommodation capability of wind power, in addition to the local electricity consumption and accommodation. While the growth of electricity demand slowed down and various areas showed oversupply of electricity, local governments generally intervened in the cross-provincial transactions, creating inter-provincial barriers. Moreover, China has not set up a market mechanism and subsidy mechanism serving peak load services, causing thermal power enterprises lack of enthusiasm to voluntarily participate in peak load adjustment. With electricity demand decline, the problem of renewable energy grid connection and accommodation has not been solved, and the 
influenced scope is enlarging, represented by wind, light and hydropower curtailment, and waste of a variety of renewable energy sources [63]. In 2016, a total of nearly 110,000 GWh was curtailed in the form of "hydropower curtailment, wind curtailment and light curtailment", about 17,000 GWh higher than the generation of the Three Gorges Hydropower Station that year [64].

In 2016, northwest China transmitted 85,100 GWh outward through the electricity transaction center, $4100 \mathrm{GWh}$ lower than that in $2015(89,500 \mathrm{GWh})$; the proportion of outward cross-region transmission of electricity of the total generation was $11.8 \%$ in 2016 and 13.2\% in 2015 [57]. Obviously even electricity marketization is promoted, the amount and proportion of cross-region electricity transmission of northwest China did not increase, but declined.

In order to solve the high wind curtailment of northwest China as soon as possible, the cross-region renewable energy increment spot transaction is placed great expectation.

From the analysis of the transmitted wind power amount in 2016 (Table 11), we can see under the optimistic condition, the cross-region wind power transmission increases by $50 \%$, the wind curtailment of Gansu may decline about 10 percentage points, and the rest two provinces see little improvement.

Table 11. Wind power generation, wind curtailment amount, wind curtailment rate and transmitted electricity of northwest provinces in 2016 [66-69].

\begin{tabular}{cccc}
\hline Item (GWh) & Xinjiang & Gansu & Ningxia \\
\hline Total wind power generation & 36,000 & 24,200 & 14,600 \\
\hline Amount of wind curtailment & 13,700 & 10,400 & 1900 \\
\hline Wind curtailment rate & $38 \%$ & $43 \%$ & $13 \%$ \\
\hline Outward transmitted electricity & 280 & 6600 & 20 \\
\hline $\begin{array}{c}\text { Proportion of transmitted wind power of the total wind } \\
\text { power generation }\end{array}$ & $0.8 \%$ & $27.3 \%$ & $1.4 \%$ \\
\hline $\begin{array}{c}\text { Optimistic scenario: wind curtailment rate with 50\% growth } \\
\text { of outward transmitted wind power }\end{array}$ & $37.0 \%$ & $32.5 \%$ & $11.6 \%$ \\
\hline
\end{tabular}

Note: The outward transmitted wind power of Ningxia is calculated by its new energy generation $250 \mathrm{GWh}$, minus the outward transmitted PV power $50 \mathrm{GWh}$.

Therefore, we can conclude that depending on outward transmission of wind power to solve the wind curtailment of northwest China is impossible. This judgment is proven by Northwest China Energy Regulatory Bureau of the National Energy Administration. According to their research (Table 12), there is a long way to go for provinces of northwest China to fully accommodate the new energy by 2020. Even with consideration of building new DC projects for outward transmission of electricity generated from new energy resources, the rate of wind curtailment and light curtailment is still expected to exceed $20 \%$ with high pressure of new energy power accommodation in Gansu and Xinjiang. In comparison, the overall rate of the new energy curtailment of Ningxia and Qinghai is about $10 \%$, indicating that they will face less pressure of new energy power accommodation. 
Table 12. Comparison of New energy accommodation simulation results of provinces of northwest China [69].

\begin{tabular}{ccccccc}
\hline & \multicolumn{2}{c}{2015} & \multicolumn{4}{c}{2020} \\
$\begin{array}{c}\text { Province } \\
\begin{array}{c}\text { Autonomous } \\
\text { Region) }\end{array}\end{array}$ & $\begin{array}{c}\text { Wind } \\
\text { Curtailment } \\
\text { Rate }\end{array}$ & $\begin{array}{c}\text { Light } \\
\text { Curtailment } \\
\text { Rate }\end{array}$ & $\begin{array}{c}\text { Without DC } \\
\text { UHV } \\
\text { Transmission } \\
\text { Line }\end{array}$ & $\begin{array}{c}\text { Without DC } \\
\text { UHV } \\
\text { Transmission } \\
\text { Line }\end{array}$ & $\begin{array}{c}\text { Constructing } \\
\text { DC UHV } \\
\text { Transmission } \\
\text { Line }\end{array}$ & $\begin{array}{c}\text { Constructing } \\
\text { DC UHV } \\
\text { Transmission } \\
\text { Line }\end{array}$ \\
\hline & & & Wind & Light & Wind & Light \\
curtailment & curtailment & curtailment & curtailment \\
Gansu & 34.6 & 38.2 & rate & rate & rate & rate \\
Ningxia & 13.2 & 8.2 & 18.2 & 49.1 & 26.6 & 29.6 \\
Xinjiang & 32.5 & 24.8 & 38.7 & 11.2 & 15.4 & 10.5 \\
Shaanxi & 0.0 & 0.9 & 5.4 & 5.6 & 25.8 & 22.4 \\
Qinghai & 2.5 & 3.2 & 5.6 & 11.4 & 3.9 & - \\
\hline
\end{tabular}

If the five provinces (autonomous regions) of northwest China can maintain the wind curtailment and light curtailment at $5 \%$ or below, the scale and proportion of wind power and PV power installed capacity of them should be as shown in Table 13. From Table 13 we can see except for Shaanxi, the planned installed capacity of new energy of the rest four provinces (autonomous regions) of northwest China has exceeded the normal accommodation capacity of the electricity system, and the wind curtailment and light curtailment of some provinces theoretically do not allow additional installed capacity of new energy before 2020. For example, Gansu can hardly control the wind curtailment below 5\% even it increases no new wind power installed capacity after 2015.

Table 13. Reasonable installed capacity of new energy for normal accommodation of new energy northwest China in 2020 [69].

\begin{tabular}{cccc}
\hline $\begin{array}{c}\text { Province } \\
\text { (Autonomous } \\
\text { Region) }\end{array}$ & $\begin{array}{c}\text { Reasonable Installed } \\
\text { Capacity of Wind } \\
\text { Power (MW) }\end{array}$ & $\begin{array}{c}\text { Reasonable } \\
\text { Installed Capacity } \\
\text { of PV Power (MW) }\end{array}$ & $\begin{array}{c}\text { Proportion of New Energy } \\
\text { Installed Capacity of Total } \\
\text { Installed Capacity (\%) }\end{array}$ \\
\hline Gansu & 11,000 & 5600 & 28.6 \\
Ningxia & 8800 & 7800 & 30.2 \\
Xinjiang & 14,000 & 7800 & 21.0 \\
Shaanxi & 5500 & 7000 & 18.0 \\
Qinghai & 2000 & 9500 & 21.6 \\
\hline
\end{tabular}

3.4.3. Incapability of Peak Load Adjustment Results in Wind and Light Curtailment of Northwest China

The two major reasons causing wind and light curtailment of northwest China are peak load adjustment incapability and limited transmission capacity of the electricity system. With development of the power grid in northwest China, the influence of the two reasons on the wind and light curtailment is changing (Table 14). In 2015 the peak load adjustment incapability was a leading element causing wind and light curtailment of the power grid of northwest China (but the constrained new energy transmission capacity cannot be neglected). In 2020, the wind and light curtailment caused by the limited transmission capacity will be very small, but the peak load adjustment incapability will be more and more serious for most provinces in northwest China. 
Table 14. Comparison of wind and light curtailment causes simulation results of provinces (autonomous regions) of northwest China [69] (Unit: \%).

\begin{tabular}{ccccc}
\hline Province & \multicolumn{2}{c}{ Peak Load Adjustment Incapability } & \multicolumn{2}{c}{ Limited Transmission Capacity } \\
\cline { 2 - 5 } (Autonomous Region) & $\mathbf{2 0 1 5}$ & $\mathbf{2 0 2 0}$ & $\mathbf{2 0 1 5}$ & $\mathbf{2 0 2 0}$ \\
\hline Gansu & 52.1 & 74.2 & 47.9 & 25.8 \\
Ningxia & 85.5 & 94.2 & 14.2 & 5.8 \\
Xinjiang & 74.1 & 92.3 & 25.9 & 7.7 \\
Shaanxi & - & 95.7 & - & 4.3 \\
\hline
\end{tabular}

\section{Conclusions}

The wind power has been connected to the power grid at a high proportion in northwest China, increasing burden of the system adjustment. Its output exceeds the system adjustment scope and causes a large amount of wind curtailment and high wind curtailment rate. This paper constructs an analytical model to explore the reasons of the high wind curtailment of Gansu Province, Xinjiang Uygur Autonomous Region and Ningxia Hui Autonomous Region from the four aspects of the wind power supply capacity, demand, grid transmission capacity, power system flexibility and market mechanism and laws. The results show that the relationship between the wind energy distribution and supply and the local load is incompatible, which is the source causing the high wind curtailment in northwest China. On the one hand, the game between the local government and developers has driven the development of wind power bases. On the other hand, the electricity sector is growing slowly and oversupply of electricity is seen in many areas of China. The wind power grid of northwest China not only faces a limit of grid transmission capacity, but also a constraint of insufficient flexibility of the electricity system. In addition, at present, China has not set up a market mechanism and subsidy mechanism for the peak load adjustment, thus the thermal power companies lack motivation to voluntarily adjust the peak load. Moreover, the regional segregation and market barriers are also obstacles for the wind power outward transmission. The above reasons lead to a large amount of wind curtailment and high wind curtailment rate in northwest region. Through exploring the factors that affect the wind curtailment in northwest China, this study can enlighten the local governments (including northwest China), investors and national policy makers in solving the serious problem of wind curtailment.

Acknowledgments: This paper is completed with support from the National Philosophy and Social Sciences Fund Project (Project No. 17BGL136) and Beijing Social Science Fund Energy Base Project "A Study on Clean Utilization and Development of Energy in Rural Area under Beijing-Tianjin-Hebei Coordinated Development" (17JDYJB011). Many thanks to Yuan Jiahai for his advice and Wang Wei for his help.

Author Contributions: Guoliang Luo and Xiaochun Zhang conceived the study idea and co-wrote the paper; Erli Dan conducted investigation, document collection and analysis and revised the paper; Yiwei Guo revised the paper.

Conflicts of Interest: The authors declare no conflict of interest.

\section{References}

1. Xin, S.; Bai, J.; Guo, Y. Study on wind power characteristics of Jiuquan wind power base. Energy Technol. Econ. 2010, 22, 16-20.

2. Zhou, Q.; Wang, B. A study on the policy of promoting long-distance transportation of Jiuquan wind power and PV power. Gansu Sci. Technol. 2013, 29, 1-5.

3. Electric Power Planning and Design Institute. Report on China's Electric Power Development 2016; China Electric Power Press: Beijing, China, 2016.

4. Niu, S.; Wang, Y.; Qu, W. Dilemma and solution of wind power industry of northwest China. Sci. Technol. Rev. 2017, 6, 25-32. 
5. Shu, Y.; Tang, Y.; Sun, H. A study on electricity system safety and stability standards. Proc. CSEE 2015, 33, $1-8$.

6. Zhou, X.; Chen, $\mathrm{S}$; $\mathrm{Nu}, \mathrm{Z}$. Review and prospect of power grid and grid technology development. Proc. CSEE 2013, 33, 1-11.

7. Luo, G.; Li, Y.; Tang, W. Wind curtailment of China's wind power operation: Evolution, causes and solutions. Renew. Sustain. Energy Rev. 2016, 53, 1190-1201. [CrossRef]

8. Cheng, L.; Bai, J. Characteristics of wind power integration in foreign countries and lessons for China. Sino-Glob. Energy 2011, 11, 30-34.

9. Wang, Z.; Zhao, Y.; Shi, J. Mid-term and long-term development map of China wind power. China Energy 2012, 34, 5-8.

10. He, G.; Kammen, D.M. When and how much wind is available? A provincial-scale wind resource assessment for China. Energy Policy 2014, 74, 116-122. [CrossRef]

11. Zhao, Y.; Wang, H. Analysis of china's renewable energy rationing and suggestions. Energy China 2015, 36, $16-22$.

12. Gao, H. China renewable energy development policy and action between 2010-2014. Energy China 2016, 38, 6-9.

13. Shi, R.; Fan, X.; He, Y. Comprehensive evaluation index system for wind power utilization levels in wind farms in China. Renew. Sustain. Energy Rev. 2017, 69, 461-471. [CrossRef]

14. Zhang, S. Is it practical to solve the problem of wind curtailment by enlarging the outward transmisson of wind power. Wind Energy 2017, 5, 34-36.

15. Wei, Q. Research on the related laws and regulations that empowering local governments to supervise the development of wind power in China. Soc. Sci. Xinjiang 2017, 3, 119-124.

16. Liu, K. Analysis on influence of wind power integration on power grid and research on solutions. Electr. Power 2012, 9, 7-10.

17. Zhang, S.; Lin, W.; Yin, G. Which is better, wind power or coal power from the perspective of fiscal revenue of the local government. Energy 2017, 5, 88-92.

18. Wang, X.; Li, J.; Huang, B. A two-stage optimal dispatching model for provincial and regional power grids connected with wind farms to promote accommodation of wind power. Power Syst. Technol. 2015, 39, 1833-1838.

19. Zhu, L.; Chen, N.; Han, H. Key problems and solutions of wind power accommodation. Autom. Electr. Power Syst. 2011, 35, 29-34.

20. Yi, B.; Xu, J.; Fan, Y. Optimal pathway and impact of achieving the mid-long term renewable portfolio standard in China. J. Syst. Eng. 2017, 32, 313-324.

21. Zhang, L.; Ye, T. Issues concerning large-scale wind power grid connection and countermeasures. Proc. CSEE 2010, 25, 19-26.

22. Zhao, X.; Wu, L.; Zhang, S. Joint environmental and economic power dispatch considering wind power integration, empirical analysis from Liaoning Province of China. Renew. Energy 2013, 52, 260-265. [CrossRef]

23. Zhao, X.; Wang, F.; Wang, M. Large-scale utilization of wind power in China, obstacles of conflict between market and planning. Energy Policy 2012, 48, 222-232. [CrossRef]

24. Cong, R. An optimization model for renewable energy generation and its application in China: A perspective of maximum utilization. Renew. Sustain. Energy Rev. 2013, 17, 94-103. [CrossRef]

25. Zhang, S.; Andrews-Speed, P.; Zhao, X.; He, Y. Interactions between renewable energy policy and renewable energy industrial policy: A critical analysis of China's policy approach to renewable energies. Energy Policy 2013, 62, 342-353. [CrossRef]

26. Jiang, L. Administrative intervention is the biggest harm to market. Energy Obs. 2017, 3, 16-20.

27. Yuan, J.; Sun, S.; Shen, J. Wind power supply chain in China. Energy Policy 2014, 39, 356-369. [CrossRef]

28. Jiang, C.; Liu, W.; Zhang, J. Risk assessment of generation and transmission systems considering wind power penetration. Trans. China Electrotech. Soc. 2014, 29, 260-270.

29. Sahu, B.K. Wind energy developments and policies in China: A short review. Renew. Sustain. Energy Rev. 2018, 81, 1393-1405. [CrossRef]

30. Shu, Y.; Zhang, Z.; Guo, J. Analysis of key elements of new energy accommodation and countermeasures. Proc. CSEE 2017, 37, 1-9. 
31. Xiong, W.; Wang, Y.; Mathiesen, B.V.; Zhang, X. Case study of the constraints and potential contributions regarding wind curtailment in Northeast China. Energy 2016, 110, 55-64. [CrossRef]

32. Guo, Y.; Ru, P.; Su, J.; Anadon, L.D. Not in my backyard, but not far away from me: Local acceptance of wind power in China. Energy 2015, 82, 722-733. [CrossRef]

33. Pei, Z.; Fan, G. A study of issues concerning wind power accommodation of China. Electr. Power 2014, 47, $1-4$.

34. Pei, Z.; He, Q.; Fan, G. Analysis of issues concerning China's new energy accommodation and suggestions. Electr. Power 2016, 49, 67-72.

35. Xiong, M.; Zhang, Y.; Yuan, J. The financial evaluation of wind power in China and policy suggestion. Energy China 2016, 38, 48-55.

36. National Renewable Energy Center. China Renewable Energy Development Report 2014; China Environmental Science Press: Beijing, China, 2014.

37. Shen, Y. Wind Energy Resources and Wind Power Generation in China. Northwest Hydropower 2010, 1, 76-81.

38. Zhang, Z.; Chen, Y. Reasons of zero wind power project in northeast, north and northwest China. State Grid 2016, 4, 45-52.

39. National Renewable Energy Center. China Renewable Energy Industry Development Report 2016; China Economic Publishing House: Beijing, China, 2016.

40. National Development and Reform Commission. Circular of the National Development and Reform Commission on Improving Onshore Wind Power and PV Power On-Grid Benchmark Pricing Policy. Available online: http://www.sdpc.gov.cn/gzdt/201512/t20151224_768582.html (accessed on 2 February 2018). (In Chinese)

41. Zhang, W. A study of unified planning mechanism of electricity system. China Power Enterp. Manag. 2014, 11, 23-31.

42. Sun, S.; Li, Z. Does electricity planning needs reform? China Power Enterp. Manag. 2016, 8, $34-41$.

43. Zhou, Q.; Wang, N. Analysis of China new energy wind and light curtailment and prospect exploration. Electr. Power 2016, 49, 54-62.

44. Sun, S.; Liu, F.; Xue, S.; Zeng, M.; Zeng, F. Review on wind power development in China: Current situation and improvement strategies to realize future development. Renew. Sustain. Energy Rev. 2015, 45, 589-599. [CrossRef]

45. National Grid Energy Research Institute. 2015 China New Energy Power Analysis Report; China Electric Power Press: Beijing, China, 2015.

46. China Electricity Council. Electric Power Development Report 2014; China Market Press: Beijing, China, 2014.

47. China Electricity Council. Electric Power Development Report 2016; China Market Press: Beijing, China, 2016.

48. China Electricity Council. Summary of Electricity Industry Statistics 2012; China Market Press: Beijing, China, 2012.

49. China Electricity Council. Summary of Electricity Industry Statistics 2013; China Market Press: Beijing, China, 2013.

50. Ren, D. Dystocia of rationing system in 10 years. State Grid 2017, 8, 9-12.

51. Li, J. On new energy accommodation must have a green development concept. State Grid 2017, 7, 8-11.

52. Huang, Q. How Does the Power Wind Industry Innovate and Develop in the 13th Five-Year Plan Period. Available online: http://news.bjx.com.cn/html/20170615/831282.shtml (accessed on 2 February 2018). (In Chinese)

53. He, N.; Feng, J. Power transmission to Hunan frustrated. Energy Obs. 2016, 6, 45-52.

54. Hunan Grid Corporation. Jiuquan-Hunan UHV Transmission Project Put into Operation. Available online: http:/ /www.hunan.gov.cn/zw/hnyw/tjdt/201706/t20170624_4289547.html (accessed on 2 February 2018). (In Chinese)

55. China Electricity Council. Summary of Electricity Industry Statistics 2016; China Market Press: Beijing, China, 2016.

56. State Grid Corporation. How to Solve the PV Power Accommodation Contradiction in 2016? Available online: http:/ / www.cet.com.cn/nypd/qy/yq/1716512.shtml (accessed on 2 February 2018). (In Chinese)

57. National Renewable Energy Center. Outlook of China Renewable Energy 2016; China Economic Publishing House: Beijing, China, 2016. 
58. Zhen, Y.; Liu, J.; Han, H. Analysis of causes of Gansu's renewable energy rationing and suggestions. Energy China 2016, 12, 15-21.

59. National Development and Reform Commission. Interpretation of Electricity System Reform; People's Publishing House: Beijing, China, 2016.

60. Chen, S. Renewable Energy Subsidy Policy Ferments a Reform. Available online: http:/ / paper.people.com. cn/zgnyb/html/2016-09/19/content_1713926.htm (accessed on 2 February 2018). (In Chinese)

61. China Electricity Council. Renewable Energy Subsidy Policy Ferments a Reform, Subsidy Gap Exceeds RMB 60 Billion. Available online: http:/ / www.cec.org.cn/xinwenpingxi/2016-09-14/158446.html (accessed on 2 February 2018). (In Chinese)

62. Yuan, J.; Zhang, W. Excess Scale of Coal Power and De-Capacity Path in China. Energy China 2017, 39, 14-20.

63. Yang, Z. Inflexibility of electricity system constrains wind power accommodation. Energy China 2017, 7, 78-83.

64. China Electricity Council. Renewable Energy Power Curtailment Reaches Nearly 110,000 GWh. Available online: http:/ / paper.people.com.cn/zgnyb/html/2017-03/27/content_1761906.htm (accessed on 2 February 2018). (In Chinese)

65. Greenpeace. China Wind Curtailment Standings in 2016. Available online: http://newenergy.in-en.com/ html/newenergy-2290498.shtml (accessed on 2 February 2018). (In Chinese)

66. China Electricity Council. 2016-2017 National Power Supply and Demand Analysis. Available online: http:/ / www.cec.org.cn/yaowenkuaidi/2017-01-25/164285.html (accessed on 2 February 2018). (In Chinese)

67. Northwest China Energy Regulatory Bureau. Northwest China Power Grid Annual Cross-Region Electricity Transaction Exceeds 100 Billion kWh for the First Time. Available online: http:/ /news.cnr.cn/native/city/ 20170112/t20170112_523473027.shtml (accessed on 2 February 2018). (In Chinese)

68. Northwest China Energy Regulatory Bureau. Ningxia New Energy Generation Exceeds 10 Billion kWh. Available online: http:/ / energy.people.com.cn/n1/2017/0710/c71661-29393480.html (accessed on 2 February 2018). (In Chinese)

69. Northwest China Energy Regulatory Bureau. Northwest China New Energy Development Planning and Operation Supervision Report. Available online: http:/ /www.nea.gov.cn/2017-06/01/c_136331393.htm (accessed on 2 February 2018). (In Chinese) 